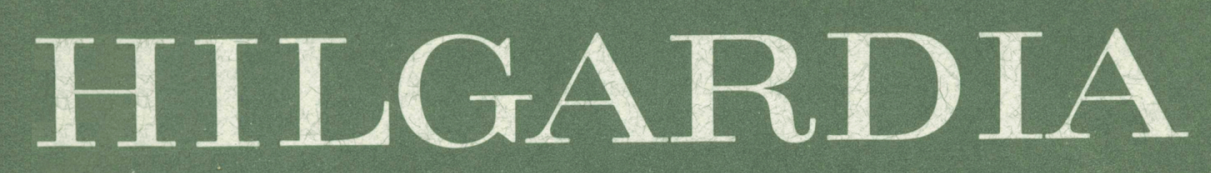

A JOURNAL OF AGRICULTURAL SCIENCE PUBLISHED BY THE CALIFORNIA AGRICULTURAL EXPERIMENT STATION

Volume 46, Number $5 \cdot J u n e, 1978$

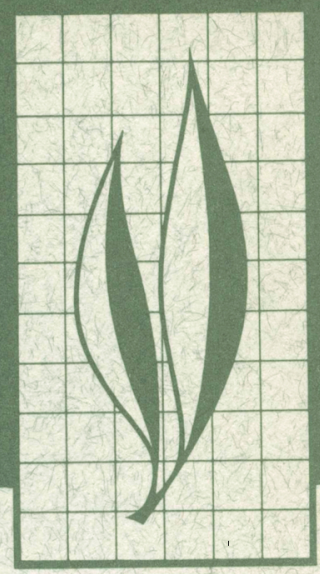

\title{
Use of Saline Irrigation Waters and Minimal Leaching for Crop Production
}

W. A. Jury, H. Frenkel, H. Fluhler, D. Devitt, and L. H. Stolzy 


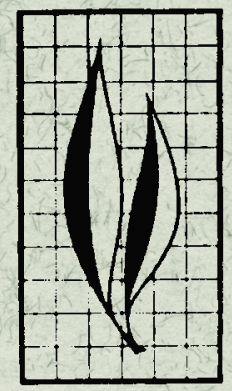

An experiment in 24 lysimeters irrigated with water at three salinity levels is reported. Two crops-wheat and sorghum, were grown in the lysimeters, each of which contained one of four soil types-two clay loams and two sandy loams. Hydraulic conductivity, water potential, and water capacity were measured as functions of volumetric water content in nine of the lysimeters at the beginning of the experiment. Afterward, wheat, followed by sorghum and a second wheat crop, were grown while irrigated with water of $2.2,4.2$, or $7.1 \mathrm{mmho}$ per $\mathrm{cm}$ electrical conductivity. There were no yield differences among treatments in the first wheat crop, because most of the growth was completed before yieldlimiting levels of soil salinity were developed. Yields in the medium- and high-salinity treatments were reduced by 6 and 28 percent, respectively, compared with yield from the low-salinity treatment. Evapotranspiration was reduced 7 and 15 percent respectively, for the same treatments. Yield and evapotranspiration were substantially reduced in all treatments of the second wheat crops. The grain yield of the low-, medium-, and high-salinity irrigation treatments averaged 76,72 , and 54 percent of the corresponding yields in the first wheat crop. Salt precipitation averaged about 55 percent of the applied amount for all salinity treatments over the entire experiment. Profile salinization was still incomplete at the end of the third crop, a consequence of the low (10 percent) leaching fractions in all lysimeters.

\section{THE AUTHORS:}

William A. Jury is Associate Professor of Soil Physics; Haim Frenkel (presently at the Institute of Soils and Water, Bet Dagan, Israel) was Associate Specialist; Hannes Fluhler is Assistant Research Soil Physicist; Dale Devitt is Staff Research Associate; and Lewis H. Stolzy is Professor of Soil Physicsall of the Department of Soil Science and Agricultural Engineering, Riverside. 


\section{Use of Saline Irrigation Waters and Minimal Leaching for Crop Production ${ }^{1}$}

\section{INTRODUCTION}

For many years, California growers have assumed that yields of crops dependent on irrigation water were limited only by its availability-and its availability had few limits. It seems clear now, however, that competition for water among users in agriculture, industry, and recreation will require increasingly efficient methods for its use in the future. One projected estimate (Moses, 1972) of future electrical generation plant requirements throughout California indicates cooling water needs sufficient to conflict seriously with agricultural water requirements.

For these reasons it is important that all water users, particularly agricultural users, efficiently manage the existing resources. For agriculture this requires applying the least amount of water consistent with achieving high crop yields and maintaining soil-water permeability. In addition alternate sources of irrigation water, such as electrical power-plant cooling water, should be investigated.

There have been several proposals made for irrigation management with limited water or high salinity. The U.S. Salinity Laboratory has proposed a minimum leaching policy aimed at keeping the root zone moist and preventing the buildup of salts by frequent irrigations applied to maintain a small but nearly continuous drainage flux out of the root zone (van Schilfgaarde et al.,
1974). Minimum leaching, although increasing the concentration of the drainage water, has been shown to minimize the salt flux out of the root zone by maximizing precipitation of salts of low solubility in the soil water, and minimizing soil mineral weathering and dissolution of previously deposited salts (Rhoades et al., 1974). Minimum leaching requires a feedback connection between evapotranspiration and irrigation, so that adjustments in applied water can be made in response to changes in consumptive use by the crop. This feedback may, in principle, be generated by soil-based sensors, such as shallow tensiometers, to schedule irrigations in conjunction with deeper salinity sensors to help achieve a desired drainage concentration and leaching fraction. However, spatial variability of solute concentrations within a root zone, coupled with the long travel time between the surface and sensor locations, create difficulties in using salinity sensors to attain a desired leaching fraction (Jury, Fluhler, and Stolzy, 1977). Irrigation feedback generated by a direct measurement of evapotranspiration (Jensen, 1975) should prove to be a more practical way of controlling drainage rates.

In addition to constraints imposed by the degree of salt tolerance of the irrigated crop, the minimum attainable leaching fraction for an entire field will

\footnotetext{
${ }^{1}$ Accepted for publication October 17, 1977.
} 
depend on the uniformity of the irrigation system. For a sprinkler system with a uniformity coefficient of 90 percent, the average leaching fraction of the field would have to be 0.25 to provide a leaching fraction of 0.05 for the part of the field receiving the least irrigation water (Jensen, 1975).

Different sites can dictate different kinds of irrigation management. King and Hanks (1975) reported on a field in which drainage waters tended to the same salt concentration regardless of the amount of water applied. For this reason, they recommended periodic leaching and reclamation of the site. Rawlins (1976) and Rhoades and Suarez (1976) gave examples of situations where different leaching fractions might be needed because of site-specific conditions.

Knowledge of soil-specific interactions-or specifically, precipitation or dissolution-that occur within the root zone is essential for salt and water management. Pratt, Davis, and Laag (1977) have shown that because of precipitation reactions, addition of manure to irrigated land sites has a negligible effect on the total salts leached below the root zone. Theoretical models (Dutt and Tanji, 1962; Tanji et al., 1967; Oster and McNeal, 1971) have been proposed to account simultaneously for precipitation, dissolution, and other chemical reactions as functions of leaching fraction and irrigation water composition. Application of this calculation to irrigation waters of various concentrations has been recently outlined by Oster and Rhoades (1975).
Minimum leaching and use of saline water for irrigation introduces the possibility of permeability degradation caused by swelling or clogging of the soil. McNeal (1968) found that the combination of high sodium and low total concentration is the most deleterious for soil-water transmission properties.

Using saline water for irrigation also may cause osmotic stress to plants rooted within the saline profile. Earlier guidelines, based on leaching requirements that related salt tolerance in the crop to average root-zone salinity, have been challenged (Bernstein, 1974; Rhoades, 1974) on the basis that salt profiles resulting from minimal leaching are not uniform; the maximum concentrations may considerably exceed the average concentrations. As a result, the maximum salt concentrations for a number of crops may exceed the "guideline" concentrations (obtained under nearly uniform salination of the root zone) without yield reductions. For this reason, drainage concentrations of crops irrigated at low leaching fractions should not be directly compared to the guideline concentrations.

The experiment described here was designed to study crop response to variations in irrigation water quality under conditions similar to those encountered in the field. As part of a program to assess the feasibility of using cooling water blowdown for electrical power generation in desert crop production, water and salt balances obtained over three growing seasons illustrated these interactions during and subsequent to profile salinization.

\section{EXPERIMENTAL DESCRIPTION}

The experiment was performed at the University of California, Riverside, in 24 steel lysimeters. Each lysimeter was $1.21 \mathrm{~m}$ in diameter and $1.5 \mathrm{~m}$ deep, had polyethylene-lined sides, and a pea gravel-filled base which drained into an outside receiving tank. The lysimeters were filled with top soil from one of four soil types (see Table 1), and had been in continuous use since 1957. As a result, their soil structure and bulk density distribution now were typical of field conditions. Salinity sensors and combination tensiometer-solution samplers 
TABLE 1

SOME CHARACTERISTICS OF THE FOUR LYSIMETER SOILS USED IN THESE TESTS*

\begin{tabular}{|c|c|c|c|c|}
\hline Soil no. and series & $\mathbf{p H}$ & $\mathrm{CaCO}_{3}$ & $\begin{array}{c}\text { Water at } \\
\text { saturation }\end{array}$ & $\mathrm{CEC}+$ \\
\hline & \multicolumn{3}{|c|}{ percent } & $m e q / g$ \\
\hline $\begin{array}{l}\text { 1. San Emigdio } \\
\text { sandy loam }\end{array}$ & 7.3 & 0.28 & 28 & 0.14 \\
\hline $\begin{array}{l}\text { 2. Greenfield } \\
\text { sandy loam }\end{array}$ & 6.8 & 0.01 & 25 & 0.08 \\
\hline $\begin{array}{l}\text { 3. Altamont } \\
\text { clay loam }\end{array}$ & 7.2 & 0.10 & 48 & 0.27 \\
\hline $\begin{array}{l}\text { 4. Holtville } \\
\text { clay loam }\end{array}$ & 7.8 & 6.60 & 44 & 0.17 \\
\hline
\end{tabular}

* Soils in these lysimeters were used in previous experiments. Data here was reported by Pratt et al. (1967). $\dagger \mathrm{CEC}=$ cation exchange capacity.

TABLE 2

COMPOSITION OF SYNTHESIZED IRRIGATION WATER USED IN LYSIMETERS

\begin{tabular}{lrrrr|rrrrr}
\hline \hline $\begin{array}{c}\text { Salinity } \\
\text { level }\end{array}$ & $\mathrm{Ca}$ & $\mathrm{Mg}$ & $\mathrm{Na}$ & $\mathrm{Cl}$ & $\mathrm{HCO}_{3}$ & $\mathrm{SO}_{4}$ & $\mathrm{EC}^{*}$ & $\mathrm{pH}$ & $\mathrm{SAR}^{*}$ \\
\hline \multicolumn{7}{c}{$m e q / l$} \\
High & 28.9 & 21.1 & 50.0 & 28.0 & 5.0 & 67.0 & 7.1 & 8.1 & 10.46 \\
Medium & 14.5 & 7.4 & 26.3 & 11.4 & 4.1 & 32.7 & 4.2 & 8.3 & 7.98 \\
Low & 8.0 & 4.3 & 11.1 & 6.3 & 3.8 & 13.3 & 2.1 & 8.0 & 4.56 \\
\hline
\end{tabular}

* EC $=$ electrical conductivity.

$\dagger \mathrm{SAR}=$ sodium adsorption ratio.

were installed at depths of $5,20,50,80$, and $120 \mathrm{~cm}$. They were replicated three times in the high-salinity lysimeter and twice in the other lysimeters. Neutron access tubes were placed at the center of each lysimeter, and water content readings were taken periodically at four depths $(20,50,80,120 \mathrm{~cm})$. Four-probe electrodes were used to measure soil electrical conductivity (Rhoades and van Schilfgaarde, 1975).

Three concentration levels of synthesized irrigation water (Table 2), similar to cooling-tower blowdown water, were used. Even the low-salinity treatment was more concentrated than typical irrigation water (Rhoades et al., 1973).

In a preliminary experiment, nine of the lysimeters were wetted to saturation with tap water from the bottom up, covered, and allowed to drain. Tensiometer readings and neutron-probe values were taken periodically during drainage, and water-transport characteristics were determined using the instantaneous profile method (Rose, Stern, and Drummond, 1965). These characteristics had considerable scatter, although significant differences were not found among different horizons or among different lysimeters of the same soil type. Determinations of hydraulic conductivity, soil-water matric potential, and water capacity as functions of volumetric water content were made for the soils within these lysimeters. In February, 1976, an experiment was initiated to study the influence on crop response of high-frequency irrigation of saline water at low leaching fractions. Water was applied to the lysimeters at one of three salinity levels shown in Table 2. Applied irrigation at full cover slightly exceeded the average potential evapotranspiration for the previous week-as determined by solar radiation, temperature, humidity, and wind-run measurements to calculate the Penman evapo- 
transpiration estimate (Doorenbos and Pruitt, 1975).

Initially, each lysimeter was ponded twice with $2 \mathrm{~cm}$ of the appropriate irrigation water. To maintain sufficiently low salt concentrations in the seed bed for germination, all lysimeters were irrigated with $2.3 \mathrm{~cm}$ of tap water during the fourth day. On the sixth day, winter wheat (Triticum aestivum, var. Cahemi 71) was planted in all lysimeters. The mature wheat was harvested between June 9 and 16, 1976. On July 12, 1976, grain sorghum was planted in each lysimeter, and the irrigations were continued. The forage was cut in mid-December, 1976. A second wheat crop was

\section{THEORETICAL DESCRIPTION}

\section{Water transport model}

The water model used in this investigation was an extension of a gravity flow system (unit hydraulic gradient) (Jury, Fluhler, and Stolzy, 1977) based upon the following assumptions: i) the soil profile is divided into six equal layers; ii) water movement is assumed to be downward and to occur at a rate characteristic of the value of the soil hydraulic conductivity associated with the water content of the overlying layer at any given time; iii) the fraction of the total water uptake extracted from a given layer is a function only of depth; iv) the total daily evapotranspiration and irrigation are the values measured in the experiment.

Under these assumptions, the equations to be solved for each layer are

$$
H \frac{d \theta_{j}}{d t}=K\left(\theta_{j-1}\right)-K\left(\theta_{j}\right)-S_{j} \quad j=1,6
$$

where $H$ is the thickness of each layer (here $20 \mathrm{~cm}$ ), $K\left(\theta_{j}\right)$ is the soil hydraulic conductivity, $S_{j}$ is the fraction of the evapotranspiration extracted from layer $j$, and $K\left(\theta_{0}\right)$ is the irrigation rate $F(t)$. planted in January, 1977, and harvested in June, 1977.

During each growing season, weekly measurements were made with a neutron probe, salinity sensors, and tensiometers. Water and salt balances were calculated biweekly for each lysimeter, and evapotranspiration was determined as the difference between water input, water output, and changes in soilwater storage. In April, 1977, a complete ionic composition analysis was made from solution samples taken from the lysimeters. Root density was determined in one lysimeter which had to be dismantled at the conclusion of the first experiment.

The assumptions made in constructing this model are specific to our experimental system. Continuous irrigation exceeding the atmospheric demand results in downward flow through the profile, so that the assumption of unit hydraulic gradient is a reasonable representation (Rawlins, 1974).

\section{Salt flow model}

The output of the water model is a representation of the water flux $K(z, t)$ and water content $\theta(x, t)$. This is used as input to the salt flow equation

$$
\frac{\partial(\theta C)}{\partial t}=\frac{\partial}{\partial Z}\left(\theta D \frac{\partial C}{\partial Z}\right)-\frac{\partial\left(J_{w} C\right)}{\partial Z}
$$

where $C$ is the solution concentration, $J_{w}$ is the soil water flux, and $D$ is the effective dispersion coefficient. Equation (1) was solved by Runge-Kutta integration with iteration and a variable time step. Equation (2) was solved by explicit finite difference using various space step sizes down to $1 \mathrm{~cm}$ and a time step of one day. The calculations were made on the IBM $360 / 50$ computer, requiring approximately 30 seconds of 
computer time at a cost of $\$ 1.00$ per 100 days of output. Use of finite differences with a large space grid creates some numerical dispersion which changes the effective value of $D$. With smaller space values it was determined that dispersion plays only a minor role in solute transport for short-term transient simulations.

\section{Chemical equilibrium calculations}

The model calculating ionic equilibrium between solution and soil has been described elsewhere (Oster and Rhoades, 1975). The calculation accounts for dissociation, and precipitation or dissolution of the major ions in soil water, including the carbonate species.

\section{EXPERIMENTAL RESULTS}

\section{Determination of soil hydraulic properties}

Interception of the water flux at $\mathbf{1 5 0}$ $\mathrm{cm}$ by the drainage system of each lysimeter permitted a closed water balance to be performed over the top $\mathbf{1 5 0}$ $\mathrm{cm}$. Soil-water storage changes were determined directly by neutron-probe readings and indirectly by changes in the soil water matric potential read from the tensiometers.

Nine of the lysimeters were wetted to saturation from below, covered, and allowed to drain. We assume that the nonlinear water flow equation describes the drainage process

$$
\frac{\mathrm{d} \theta}{\mathrm{d} t}=\frac{\mathrm{\partial}}{\mathrm{\partial} Z}\left(K(h)\left(\frac{\mathrm{\partial} h}{\mathrm{~d} Z}+1\right)\right.
$$

where $\theta$ is volumetric water content, $h$ is soil water pressure head and $K(h)$ is hydraulic conductivity. Integrating equation (3) over depth intervals between the surface (where the input flux is zero) and the bottom of the lysimeter (where the output flux is measured) results in an expression for $K(h)$ within each depth interval at any specific time, expressed as functions of $\mathrm{d} \theta / \partial t$ and $\mathrm{d} h / \mathrm{d} Z$, which were determined from neutron-probe readings and tensiometer readings, respectively. Comparison of $h$ and $\theta$ values for similar depth and time intervals gives the retention curve $h(\theta)$.

This in situ measurement contains numerous sources of error. Replicated tensiometer readings must be averaged and differentiated with depth to give the water potential gradient. Neutronprobe readings are averaged over a large area in the vicinity of the source. Also, lateral variations in water flow within the lysimeter, and in drainage flux out the bottom, are averaged in the process of fitting the data to a one-dimensional flow equation.

Figure 1 is a plot of the hydraulic conductivity $K(\theta)$ measured during the transient drainage experiment for the

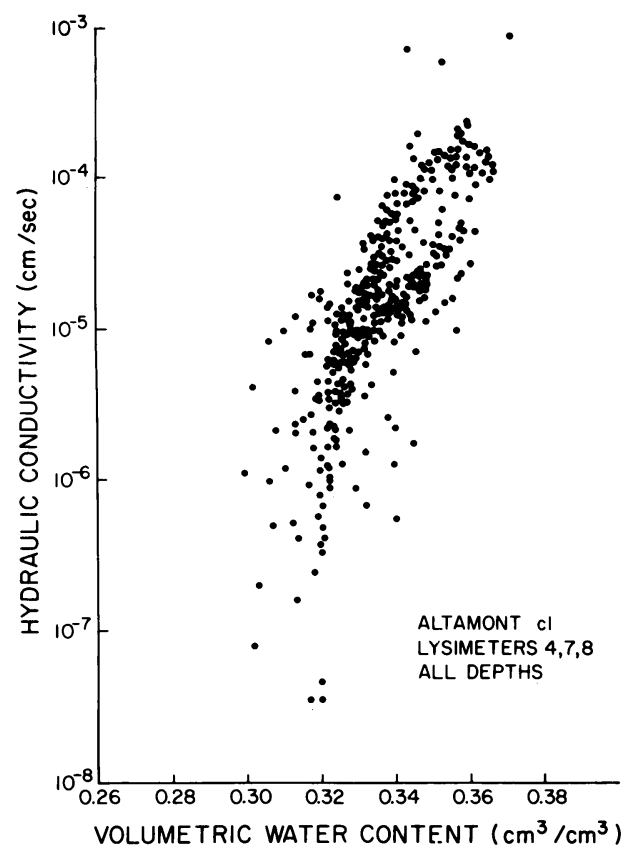

Fig. 1. Hydraulic conductivity vs. water content for all lysimeters containing Altamont clay loam. 


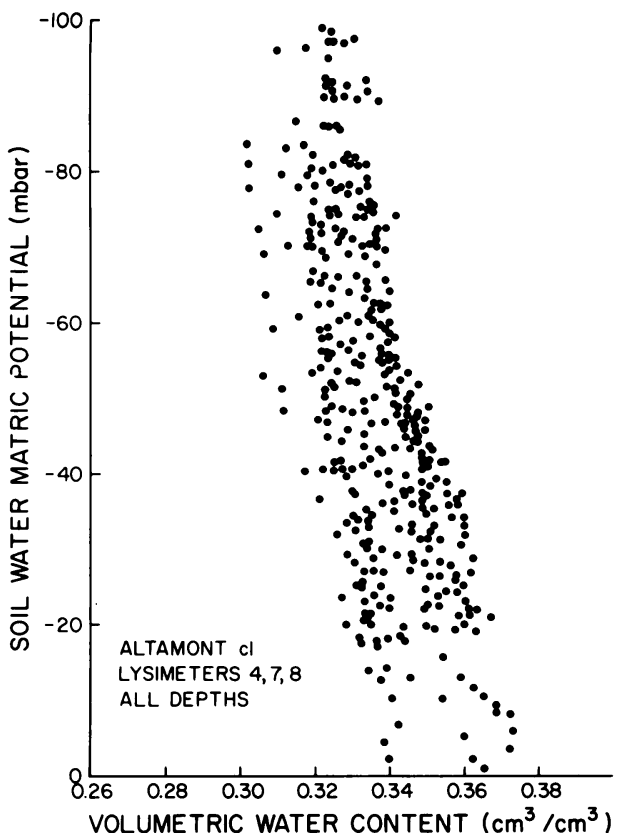

Fig. 2. Matric potential vs. water content for all lysimeters containing Altamont clay loam.

three Altamont clay loam lysimeters. The large amount of scatter is typical of field-measured hydraulic conductivities (Fluhler et al., 1977). Consequently, one must specify a distribution or confidence interval as well as the mean value of hydraulic conductivity at a given moisture content. A similar variability was present in the soil-moisture characteristic measured during the transient drainage experiment for the same three Altamont clay loam lysimeters (Fig. 2). The large variation in soil-water transport characteristics found within a narrow surface area $\left(1.1 \mathrm{~m}^{2}\right)$ points out the difficulties involved with inferring water transport from soil-based measurements.

\section{First wheat experiment}

Irrigation of wheat with the saline waters began on February 1, 1976. This experiment represented a transition period during which soil salinity increased with time, although average root-zone concentrations remained low

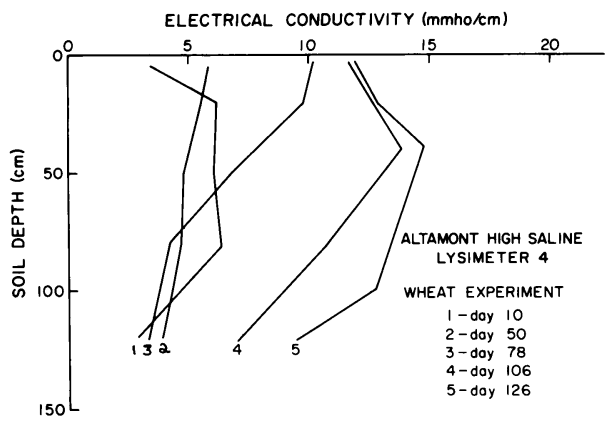

Fig. 3. Profile salinization in high-salinity lysimeter during wheat experiment.

because of the initially unsalinized profile. Typical profile data are shown in Fig. 3 for the high-salinity $(7.1 \mathrm{mmho} /$ cm) treatment of the Altamont clay loam lysimeter. The region of high salinity gradually moved downward in the profile, but even at the end of the 130-day period a steady state distribution had not been attained.

\section{I5 DAYS AFTER START OF HIGH SALINE WATER APPLICATION}

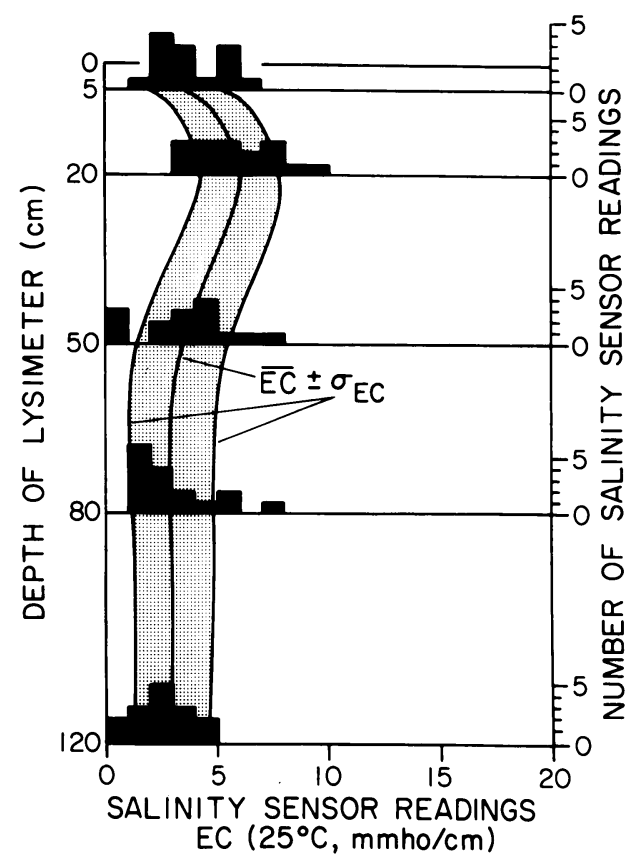

Fig. 4. Distribution of salinity sensor readings after 15 days of high-saline irrigation. 
109 DAYS AFTER START OF HIGH SALINE WATER APPLICATION

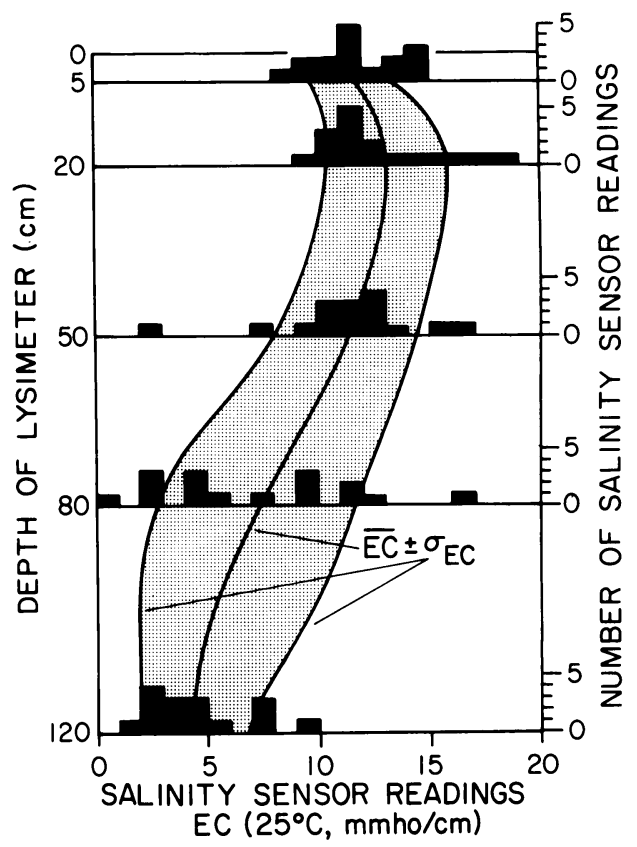

Fig. 5. Distribution of salinity sensor readings after 109 days of high-saline irrigation.

Soil salinity as determined from salinity sensors was quite variable in the lysimeters. In the wheat experiment, all high-salinity treatments were given identical irrigations through day 110 . By grouping all such treatments together, one can form a distribution of all replicate sensor readings at a given depth and time (Fig. 4) 7 days after initiation of the experiment, and again (Fig. 5) after 109 days. The variations in solute concentrations among treatments receiving the same water and salt input were large and increased with time, which could have been caused by differences in soil type, evapotranspiration, or water uptake distribution.

The latter possibility was shown in a simulation study to have the largest effect on solute concentration within the root zone (Jury, Fluhler, and Stolzy, 1977). Since a uniform irrigation treatment resulted in significant variation in sensor readings at a given depth and time, it is unlikely that these same sensors could have been used as feedback to guide irrigation applications, particularly in the transitional stage of the experiment.

Evapotranspiration was determined at discrete time intervals by conducting a water balance over each lysimeter and determining consumptive use by difference.

$$
E T=I-D-\triangle S
$$

where $I, D$, and $E T$ are cumulative irrigation, drainage, and evapotranspiration, respectively, during a given time interval, and $\triangle S$ is the change in water storage detected by neutron-probe readings. Figure 6 shows a frequency diagram for evapotranspiration readings obtained in all lysimeters during three time intervals of the wheat experiment. The rather high apparent $E T$ readings during the last period of the experiment were undoubtedly enhanced by local advection caused by dry bare soil surrounding each lysimeter.

Table 3 gives the water balance data for each of the lysimeters during the

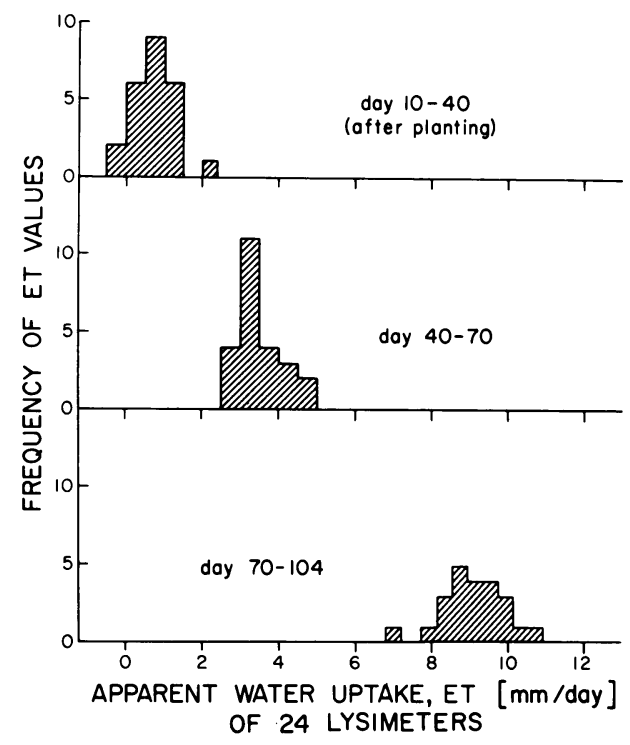

Fig. 6. Evapotranspiration distribution during wheat experiment. 
TABLE 3

WATER BALANCE FOR FIRST WHEAT CROP

(FEB. 1 TO JUNE 4, 1976)

\begin{tabular}{|c|c|c|c|c|c|c|}
\hline $\begin{array}{c}\text { Lysimeter } \\
\text { no. }\end{array}$ & $\begin{array}{c}\text { Salinity } \\
\text { level }\end{array}$ & Irrigation & Drainage & $\begin{array}{l}\text { Storage } \\
\text { change }\end{array}$ & ET* & $\mathrm{LF} \dagger$ \\
\hline \multicolumn{7}{|c|}{ centimeters } \\
\hline \multicolumn{7}{|c|}{ Holtville clay loam } \\
\hline 1 & high & 79.7 & 2.7 & 2.1 & 74.9 & 0.03 \\
\hline 10 & high & 75.9 & 1.6 & 1.3 & 73.0 & 0.02 \\
\hline 6 & med & 75.0 & 1.5 & 5.0 & 68.5 & 0.02 \\
\hline 26 & low & 72.4 & 2.9 & 1.1 & 68.4 & 0.04 \\
\hline \multicolumn{7}{|c|}{ Greenfield sandy loam } \\
\hline 2 & high & 71.2 & 0.0 & 7.3 & 63.9 & 0.00 \\
\hline 11 & high & 74.9 & 0.3 & 8.8 & 65.8 & 0.00 \\
\hline 12 & med & 76.2 & 0.8 & 7.3 & 68.1 & 0.01 \\
\hline 17 & low & 77.8 & 0.0 & 7.8 & 70.0 & 0.00 \\
\hline \multicolumn{7}{|c|}{ San Emigdio sandy loam } \\
\hline 5 & high & 77.0 & 2.7 & 6.0 & 68.2 & 0.04 \\
\hline 9 & high & 74.8 & 2.8 & 7.0 & 65.0 & 0.04 \\
\hline 14 & med & 73.1 & 2.7 & 4.9 & 65.6 & 0.04 \\
\hline 25 & low & 73.9 & 3.6 & 3.9 & 66.5 & 0.05 \\
\hline \multicolumn{7}{|c|}{ Altamont clay loam } \\
\hline 4 & high & 77.1 & 0.8 & 5.5 & 70.8 & 0.01 \\
\hline 8 & high & 76.6 & 0.2 & 2.7 & 73.7 & 0.00 \\
\hline 7 & med & 75.0 & 1.5 & 2.7 & 70.8 & 0.02 \\
\hline 18 & low & 80.1 & 0.0 & 3.7 & 76.4 & 0.00 \\
\hline
\end{tabular}

${ }^{*}$ ET $=$ evapotranspiration. Mean ET of high salinity, 69.4; mean ET of med. salinity, 68.3; mean ET of low salinity, 70.3 .

$\dagger \mathrm{LF}=$ leaching fraction.

period February 4 to June 4, 1976, of the first wheat experiment. Evapotranspiration did not vary with irrigation water salinity, indicating that yields remained high due to the high quality storage water initially present in the lysimeters. Furthermore, drainage at $150 \mathrm{~cm}$ was very low in all cases, although water storage increased between the root zone and the bottom of the lysimeters. When these storage changes are considered, the leaching fractions are somewhat higher.

Salt balances were estimated periodically with salinity sensor data and, near the end of the second wheat crop, by using an ionic composition analysis of soil solution samples. Because electrical conductivity (EC) is not directly proportional to salt concentration, a conversion from EC (mmho/cm) to C (meq/liter) was needed. This was accomplished by calculating the ionic composition of a number of multiples of our irrigation water concentrations that were exposed to various $\mathrm{CO}_{2}$ levels between .01 and $.04 \mathrm{~atm}$, using the chemical equilibrium model of Oster and Rhoades (1975), and then calculating the $\mathrm{EC}$ of the resulting mixed salt solutions by the method of McNeal, Oster, and Hatcher (1970). A plot of $E C v s$. $C$ for this system is given in Figure 7, along with the regression

$$
\ln C=1.057 \ln E C+3.06 \quad r^{2}=.9986
$$

or

$$
C \text { (meq/liter })=21.4 E C^{1.057}
$$

which converts salinity sensor readings to soil solution concentrations. Table 4 gives the salt balances for the first wheat experiment, with salt storage determined from a depth integration of the concentrations calculated using Eq. (6)

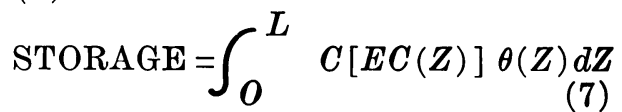


TABLE 4

TOTAL SALT BALANCE FOR FIRST WHEAT CROP

(FEB. 1 TO JUNE 4, 1976)

\begin{tabular}{|c|c|c|c|c|c|c|c|}
\hline \multirow{3}{*}{$\begin{array}{l}\text { Lysimeter } \\
\text { no. }\end{array}$} & \multicolumn{6}{|c|}{ Salt } & \multirow{3}{*}{ Precipitation } \\
\hline & \multirow{2}{*}{$\begin{array}{c}\text { Treatment } \\
\text { level }\end{array}$} & \multicolumn{2}{|c|}{ Storage } & \multirow{2}{*}{ Input } & \multirow{2}{*}{ Output } & \multirow{2}{*}{ Balance } & \\
\hline & & Initial & Final & & & & \\
\hline & \multicolumn{6}{|c|}{$\begin{array}{l}\text { milliequivalents } \\
\text { Holtville clay loam }\end{array}$} & percent \\
\hline 1 & high & 4,836 & 75,718 & 140,972 & 2,123 & 67,967 & 48 \\
\hline 10 & high & 3,932 & 46,095 & 133,465 & 750 & 90,552 & 68 \\
\hline 6 & med & 4,576 & 54,769 & 70,164 & 1,369 & 18,602 & 27 \\
\hline \multirow[t]{2}{*}{26} & low & 4,113 & 19,559 & 34,729 & 1,682 & 17,601 & 51 \\
\hline & \multicolumn{6}{|c|}{ Greenfield sandy loam } & \\
\hline 2 & high & 2,893 & 68,413 & 124,571 & 0 & 59,050 & 47 \\
\hline 11 & high & 3,232 & 56,602 & 131,532 & 0 & 78,162 & 59 \\
\hline 12 & med & 3,062 & 38,211 & 73,801 & 302 & 38,530 & 52 \\
\hline \multirow[t]{2}{*}{17} & low & 2,543 & 21,162 & 37,586 & 0 & 18,967 & 50 \\
\hline & \multicolumn{6}{|c|}{ San Emigdio sandy loam } & \\
\hline 5 & high & 3,322 & 67,807 & 135,775 & 1,439 & 99,851 & 74 \\
\hline 9 & high & 3,401 & 54,791 & 135,244 & 0 & 83,674 & 62 \\
\hline 14 & med & 3,141 & 34,296 & 70,462 & 2,099 & 37,208 & 53 \\
\hline \multirow[t]{2}{*}{25} & low & 3,017 & 14,174 & 35,533 & 1,220 & 23,156 & 65 \\
\hline & \multicolumn{6}{|c|}{ Altamont clay loam } & \\
\hline 4 & high & 4,689 & 111,970 & 135,943 & 284 & 28,378 & 21 \\
\hline 7 & med & 4,656 & 79,843 & 72,480 & 547 & $-2,894$ & -04 \\
\hline 18 & low & 3,752 & 27,776 & 38,837 & 0 & 14,813 & 38 \\
\hline
\end{tabular}

where $L$ is the depth of the lysimeter. Salt balance was calculated as the difference between salt input and output, and storage change, with a positive value corresponding to precipitation. The fraction of the input precipitated during this experiment ranged from nil to 75 percent of the salt input. Although there was substantial error from spatial variability and interpolation in the determination of salt storage (Eq. 7 ), almost all of the lysimeters registered the order of 50 percent precipitation. Leaching fraction or irrigation concentration had no apparent effect on the amount of precipitation. The Altamont cl (clay loam) treatments averaged significantly less precipitation than did the other soil types.

Table 5 shows grain and dry matter wheat yields as a function of the salinity level of the irrigation water. No significant decreases in yield were obtained with increasing salinity, indicating that much of the extracted water came from initial storage before excessive salinity developed. The mean yields of all treatments in the lysimeter on a per-hectare basis are comparable with yields for Cahemi 71 found elsewhere.

\section{Sorghum crop}

Soil salinity continued increasing during the sorghum experiment, as

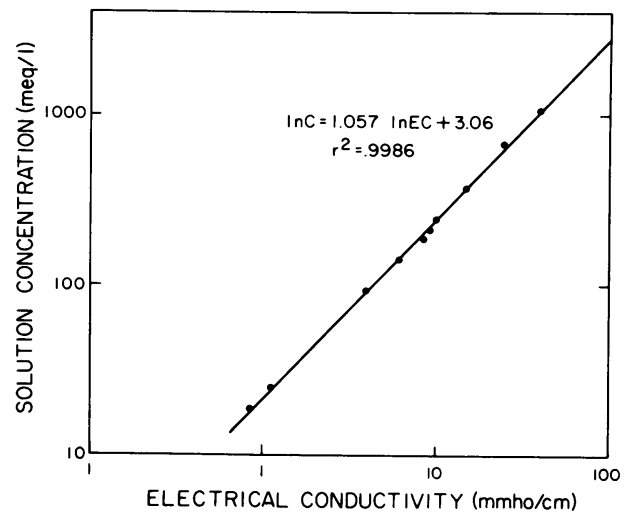

Fig. 7. Solution concentration vs. soil-water electrical conductivity calculated from chemical equilibrium model. 
TABLE 5

GRAIN AND DRY MATTER YIELDS OF LYSIMETER FIRST WHEAT CROP

\begin{tabular}{|c|c|c|c|}
\hline Treatment & $\begin{array}{c}\text { Avg. grain wt } \\
(8 \% \text { moisture) }\end{array}$ & Avg. dry matter & g/1000 seeds \\
\hline & \multicolumn{3}{|c|}{ grams } \\
\hline Low salinity & $939 a *$ & $907 \mathrm{a}$ & 32.7 \\
\hline Medium salinity & 966 a & $842 \mathrm{a}$ & 33.0 \\
\hline High salinity & $1,009 \mathrm{a}$ & 881 a & 32.5 \\
\hline \multicolumn{4}{|c|}{ 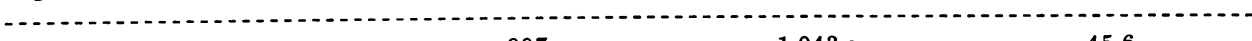 } \\
\hline Altamont clay loam & $997 \mathrm{a}$ & $1,043 \mathrm{a}$ & 45.6 \\
\hline Holtville clay loam & $1,016 \mathrm{a}$ & 939 a & 45.6 \\
\hline San Emigdio sandy loam & 960 a & $755 \mathrm{~b}$ & 47.6 \\
\hline Greenfield sandy loam & 913 a & $771 \mathrm{~b}$ & 47.5 \\
\hline
\end{tabular}

* Means followed by a common letter were not statistically separable at the $5 \%$ level.

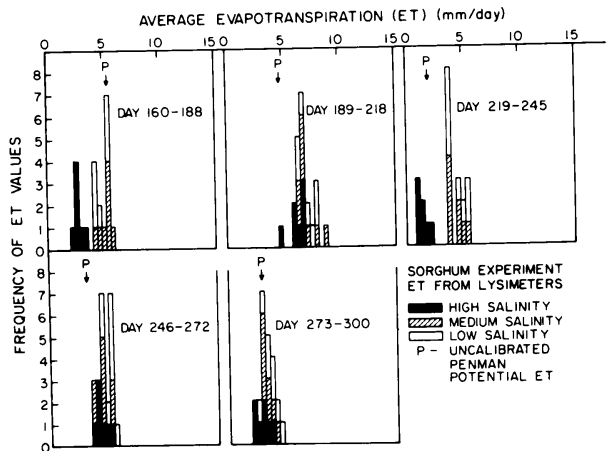

Fig. 8. Continuing profile salinization in high-salinity lysimeter during sorghum experiment.

shown in Figure 8. During this period, the depth as well as the level of salinity increased with time. However, even at the end of the experiment, steady state had not been reached.

Contrary to conditions during the first wheat crop, the soil was initially saline, so that sorghum plants and seeds were exposed to osmotic stress from the outset. Evapotranspiration was differentially reduced by these salinity levels, as shown in the frequency diagrams of Figure 9 and in the cumulative average ET values for all lysimeters shown in Figure 10. In addition, there was evidence of differences in evapotranspiration according to soil texture, with the coarser-textured soils having the larger reductions in ET. During the latter stages of the sorghum experiment, irri-

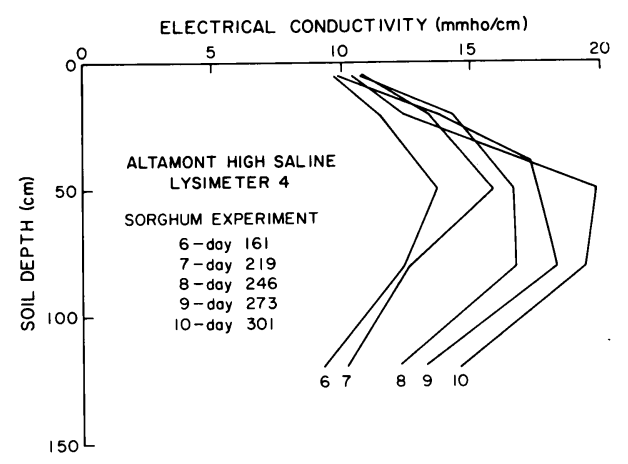

Fig. 9. Evapotranspiration distribution by treatment.

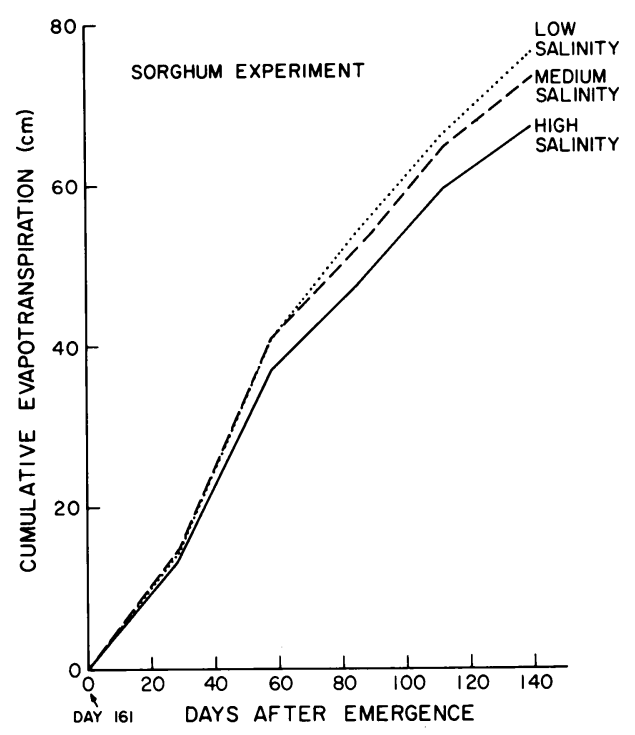

Fig. 10. Cumulative evapotranspiration by treatment for sorghum experiment. 
TABLE 6

WATER BALANCE FOR SORGHUM CROP

(JULY 16 TO DEC., 1976)

\begin{tabular}{|c|c|c|c|c|c|c|}
\hline $\begin{array}{c}\text { Lysimeter } \\
\text { no. }\end{array}$ & $\begin{array}{c}\text { Salinity } \\
\text { level }\end{array}$ & Irrigation & Drainage & $\begin{array}{l}\text { Storage } \\
\text { change }\end{array}$ & $\mathbf{E T *}$ & $\mathrm{LF}+$ \\
\hline \multicolumn{7}{|c|}{ centimeters } \\
\hline \multicolumn{7}{|c|}{ Holtville clay loam } \\
\hline 5 & high & 78.1 & 10.7 & 5.3 & 62.1 & 0.14 \\
\hline 10 & high & 74.1 & 0.3 & 5.2 & 69.2 & 0.00 \\
\hline 6 & med & 81.5 & 6.2 & 6.9 & 68.4 & 0.08 \\
\hline 26 & low & 81.9 & 0.0 & 4.3 & 77.6 & 0.00 \\
\hline \multicolumn{7}{|c|}{ Greenfield sandy loam } \\
\hline 2 & high & 77.3 & 1.6 & 4.6 & 71.0 & 0.02 \\
\hline 11 & high & 78.9 & 16.0 & 3.5 & 59.4 & 0.20 \\
\hline 12 & med & 81.5 & 0.4 & 6.1 & 75.0 & 0.00 \\
\hline 17 & low & 81.9 & 0.0 & 3.2 & 78.6 & 0.00 \\
\hline \multicolumn{7}{|c|}{ San Emigdio sandy loam } \\
\hline 5 & high & 77.1 & 7.8 & 3.4 & 65.8 & 0.10 \\
\hline 9 & high & 76.7 & 11.9 & 2.2 & 62.6 & 0.16 \\
\hline 14 & med & 79.3 & 5.0 & 6.2 & 68.1 & 0.06 \\
\hline 25 & low & 81.0 & 1.4 & 4.6 & 75.8 & 0.02 \\
\hline \multicolumn{7}{|c|}{ Altamont clay loam } \\
\hline 4 & med & 78.9 & 2.8 & 3.8 & 72.3 & 0.04 \\
\hline 7 & high & 81.2 & 0.0 & 3.0 & 78.1 & 0.00 \\
\hline 18 & low & 81.5 & 0.2 & 1.6 & 79.7 & 0.00 \\
\hline
\end{tabular}

* ET = evapotranspiration. Mean ET of high salinity, 66.1; mean ET of med salinity, 72.4; mean ET of low salinity, 77.9.

$\dagger \mathrm{LF}=$ leaching fraction.

gations were scaled to individual evapotranspiration rates to achieve more uniform leaching fractions.

Table 6 shows the final water balances for each lysimeter. The leaching fractions range from near 0 to more than 0.2. The salt balances calculated from solution EC using Eq. (6) are shown in Table 7. Precipitation during this experiment increased compared to the first wheat experiment, from 47 to 67 percent of applied salt. The two lysimeters with minimal precipitation during the wheat experiment had very high losses in the sorghum experiment, which may indicate an error in storage calculation occurred at the end of the wheat crop.

Final grain and dry matter sorghum yields are shown in Table 8 . Contrary to data from tests with the earlier wheat crop, there were definite reductions in sorghum yield among the high-, medium-, and low-salinity treatments, as well as some indication that soil type was a factor.

\section{Second wheat crop}

Average soil salinity was high throughout the second wheat crop from January 15 to June 6, 1977 (Fig. 11). Salinity increased at all depths during this experiment; in particular, average EC at 5-cm depth was approximately 1.7 times the irrigation EC. This indicated that about 40 percent of the water uptake was occurring within $5 \mathrm{~cm}$ of the surface, since the leaching fraction of this lysimeter was approximately zero. The water balance (Table 9), showed ET reductions of 19 percent and 9 percent for the high- and mediumirrigation treatments compared with the low treatment. In addition, all three treatments used less water than the first wheat crop (Table 3). Salt balances based on transformed EC readings are shown in Table 10. Average precipitation continued to exceed 50 percent for most treatments, with no significant differences by leaching fraction, irrigation treatment, or soil type. 
TABLE 7

TOTAL SALT BALANCE FOR SORGHUM CROP (JULY 16 TO DEC., 4, 1976)

\begin{tabular}{|c|c|c|c|c|c|c|c|}
\hline \multirow{2}{*}{$\begin{array}{c}\text { Lysimeter } \\
\text { no. }\end{array}$} & \multirow{2}{*}{ Salinity } & \multicolumn{2}{|c|}{ Salt storage } & \multirow{2}{*}{$\begin{array}{l}\text { Salt } \\
\text { input }\end{array}$} & \multirow{2}{*}{$\begin{array}{l}\text { Salt } \\
\text { output }\end{array}$} & \multirow{2}{*}{$\begin{array}{c}\text { Salt } \\
\text { balance }\end{array}$} & \multirow{2}{*}{ Precipitation } \\
\hline & & Initial & Final & & & & \\
\hline \multicolumn{7}{|c|}{ milliequivalents } & percent \\
\hline \multicolumn{8}{|c|}{ Holtville clay loam } \\
\hline 1 & high & 75,718 & 122,030 & 130,458 & 16,581 & 67,565 & 52 \\
\hline 10 & high & 46,095 & 115,086 & 133,465 & 749 & 86,621 & 65 \\
\hline 6 & med & 54,769 & 67,260 & 74,003 & 9,979 & 51,173 & 69 \\
\hline 26 & low & 19,559 & 37,145 & 39,775 & 0 & 22,189 & 56 \\
\hline \multicolumn{8}{|c|}{ Greenfield sandy loam } \\
\hline 2 & high & 68,413 & 116,076 & 129,087 & 1,643 & 79,781 & 62 \\
\hline 11 & high & 56,602 & 106,521 & 132,466 & 16,988 & 65,559 & 49 \\
\hline 12 & med & 38,211 & 58,077 & 74,004 & 298 & 53,840 & 73 \\
\hline 17 & low & 21,162 & 30,541 & 39,774 & 0 & 30,395 & 76 \\
\hline \multicolumn{8}{|c|}{ San Emigdio sandy loam } \\
\hline 5 & high & 67,807 & 101,615 & 128,702 & 27,211 & 67,683 & 53 \\
\hline 9 & high & 54,791 & 73,968 & 203,104 & 24,251 & 159,676 & 79 \\
\hline 14 & med & 34,296 & 47,341 & 71,932 & 13,110 & 45,777 & 64 \\
\hline 25 & low & 14,174 & 35,991 & 39,775 & 4,422 & 13,536 & 34 \\
\hline \multicolumn{8}{|c|}{ Altamont clay loam } \\
\hline 4 & high & 11,970 & 155,740 & 132,190 & 2,429 & 85,991 & 65 \\
\hline 7 & med & 79,843 & 77,805 & 73,682 & 0 & 75,720 & 103 \\
\hline 18 & low & 27,776 & 28,129 & 40,471 & 0 & 40,118 & 99 \\
\hline
\end{tabular}

TABLE 8

GRAIN AND DRY MATTER YIELDS* OF SORGHUM CROP

\begin{tabular}{l|c|c}
\hline \multicolumn{1}{c|}{ Treatment } & $\begin{array}{c}\text { Avg. grain wt } \\
(8 \% \text { moisture })\end{array}$ & grams \\
\hline & & Avg. forage wt \\
Low salinity & $844 \mathrm{a}$ & $1477 \mathrm{a}$ \\
Medium salinity & $790 \mathrm{a}$ & $1229 \mathrm{~b}$ \\
High salinity & $612 \mathrm{~b}$ & $975 \mathrm{~b}$ \\
\hline Altamont clay loam & $950 \mathrm{a}$ & $1881 \mathrm{a}$ \\
Holtville clay loam & $674 \mathrm{~b}$ & $1141 \mathrm{~b}$ \\
San Emigdio sandy loam & $630 \mathrm{~b}$ & $962 \mathrm{c}$ \\
Greenfield sandy loam & $736 \mathrm{~b}$ & $1076 \mathrm{bc}$ \\
\hline
\end{tabular}

* Means followed by a common letter were not statistically separable at the $5 \%$ level.

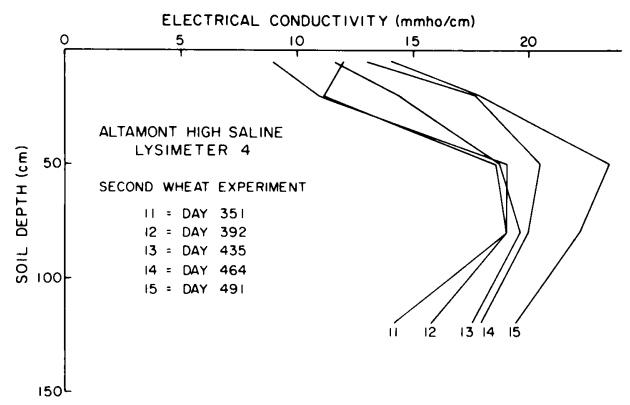

Fig. 11. Continuing profile salinization in high-salinity lysimeter during second wheat experiment.
In grain and dry matter yields (Table 11), there were highly significant differences among treatments and among soils, with the Altamont clay lysimeters continuing to produce higher yields than the other soil types. Yields for all treatments were substantially lower than for corresponding treatments in the first wheat experiment (Table 5).

\section{Salt balance from solution samples}

Table 12 shows ionic composition 
TABLE 9

WATER BALANCE FOR SECOND WHEAT CROP (JANUARY 16 TO JUNE 8, 1977)

\begin{tabular}{|c|c|c|c|c|c|c|}
\hline $\begin{array}{c}\text { Lysimeter } \\
\text { no. }\end{array}$ & $\begin{array}{c}\text { Salt } \\
\text { treatment }\end{array}$ & Irrigation & Drainage & $\begin{array}{l}\text { Storage } \\
\text { change }\end{array}$ & $\mathbf{E T *}$ & $\mathrm{L} F \dagger$ \\
\hline \multicolumn{7}{|c|}{ Centimeters } \\
\hline \multicolumn{7}{|c|}{ Holtville clay loam } \\
\hline 1 & high & 52.4 & 4.1 & 0.7 & 47.7 & 0.08 \\
\hline 10 & high & 52.4 & 0.3 & 4.5 & 47.7 & 0.01 \\
\hline 6 & med & 57.0 & 7.2 & -0.7 & 50.5 & 0.13 \\
\hline 16 & med & 57.0 & 3.4 & -1.5 & 55.1 & 0.06 \\
\hline 19 & low & 61.9 & 4.6 & 0.2 & 57.1 & 0.07 \\
\hline 26 & low & 61.9 & 0.6 & 4.2 & 57.1 & 0.01 \\
\hline \multicolumn{7}{|c|}{ Greenfield sandy loam } \\
\hline 2 & high & 52.4 & 0.2 & 0.0 & 52.2 & 0.00 \\
\hline 11 & high & 52.4 & 5.7 & 0.2 & 46.6 & 0.11 \\
\hline 12 & med & 57.0 & 8.2 & -2.0 & 50.8 & 0.14 \\
\hline 15 & med & 57.0 & 5.0 & 1.1 & 50.9 & 0.09 \\
\hline 17 & low & 61.9 & 0.8 & 2.2 & 58.8 & 0.01 \\
\hline 27 & low & 61.9 & 3.3 & -3.5 & 55.0 & 0.05 \\
\hline \multicolumn{7}{|c|}{ San Emigdio sandy loam } \\
\hline 5 & high & 52.4 & 3.9 & 1.0 & 47.5 & 0.07 \\
\hline 9 & high & 52.4 & 2.7 & 2.4 & 47.3 & 0.05 \\
\hline 14 & med & 57.0 & 3.0 & -1.0 & 55.0 & 0.05 \\
\hline 24 & med & 57.0 & 4.9 & -1.3 & 53.5 & 0.09 \\
\hline 21 & low & 61.9 & 6.2 & -0.5 & 56.2 & 0.10 \\
\hline 25 & low & 61.9 & 1.6 & 0.2 & 60.1 & 0.03 \\
\hline \multicolumn{7}{|c|}{ Altamont clay loam } \\
\hline 4 & high & 52.4 & 0.6 & 0.7 & 51.1 & 0.01 \\
\hline 7 & med & 57.0 & 0.0 & -4.4 & 61.4 & 0.00 \\
\hline 23 & med & 57.0 & 0.1 & 0.4 & 56.5 & 0.00 \\
\hline 18 & low & 61.9 & 0.0 & -1.7 & 63.6 & 0.00 \\
\hline 28 & low & 61.9 & 0.0 & 0.8 & 61.0 & 0.00 \\
\hline
\end{tabular}

* ET $=$ evapotranspiration. Mean ET of high salinity- $48.6 \mathrm{~cm} ;$ mean ET of med salinity-54.3 $\mathrm{cm} ; \mathrm{mean}$ ET of low salinity $-59.9 \mathrm{~cm}$

$\dagger \mathrm{LF}=$ leaching fraction.

TABLE 10

TOTAL SALT BALANCE FOR SECOND WHEAT CROP (JAN. 16 TO JUNE 8, 1977)

\begin{tabular}{|c|c|c|c|c|c|c|c|}
\hline \multirow{2}{*}{$\begin{array}{c}\text { Lysimeter } \\
\text { no. }\end{array}$} & \multirow{2}{*}{$\underset{\text { Salinity }}{\text { level }}$} & \multicolumn{2}{|c|}{ Salt storage } & \multicolumn{3}{|c|}{ Salt } & \multirow{2}{*}{ Precipitation } \\
\hline & & Initial & Final & Input & Output & Balance & \\
\hline & \multicolumn{6}{|c|}{ milliequivalents } & percent \\
\hline & \multicolumn{7}{|c|}{ Holtville clay loam } \\
\hline 1 & high & 122,030 & 146,600 & 91,904 & 10,606 & 56,728 & 62 \\
\hline 10 & high & 115,086 & 154,476 & 91,904 & 0 & 52,513 & 57 \\
\hline 6 & med & 67,260 & 76,839 & 55,676 & 17,579 & 28,518 & 51 \\
\hline \multirow[t]{2}{*}{26} & low & 37,145 & 60,359 & 31,476 & 853 & 7,409 & 24 \\
\hline & \multicolumn{7}{|c|}{ Greenfield sandy loam } \\
\hline 2 & high & 116,076 & 122,189 & 91,905 & 0 & 85,792 & 93 \\
\hline 11 & high & 106,521 & 130,187 & 91,905 & 15,083 & 53,156 & 58 \\
\hline 12 & med & 58,077 & 76,699 & 55,676 & 11,191 & 25,863 & 46 \\
\hline \multirow[t]{2}{*}{17} & low & 30,541 & 47,782 & 31,476 & 537 & 13,698 & 44 \\
\hline & \multicolumn{7}{|c|}{ San Emigdio sandy loam } \\
\hline 5 & high & 101,615 & 117,802 & 91,905 & 16,922 & 58,796 & 64 \\
\hline 9 & high & 73,968 & 98,293 & 91,307 & 8,364 & 58,618 & 64 \\
\hline 14 & med & 47,341 & 61,042 & 55,725 & 8,584 & 33,440 & 60 \\
\hline \multirow[t]{2}{*}{25} & low & 35,991 & 41,480 & 31,476 & 3,713 & 22,274 & 71 \\
\hline & \multicolumn{7}{|c|}{ Altamont clay loam } \\
\hline 4 & high & 155,740 & 206,422 & 91,905 & 1,477 & 39,746 & 30 \\
\hline$\overline{7}$ & med & 77,805 & 100,910 & 55,725 & 0 & 32,620 & 59 \\
\hline 18 & low & 28,129 & 34,260 & 31,476 & 0 & 25,345 & 81 \\
\hline
\end{tabular}


TABLE 11

GRAIN AND DRY MATTER YIELDS* OF SECOND WHEAT CROP

\begin{tabular}{l|c|c|c}
\hline \hline \multicolumn{1}{c|}{ Treatment } & $\begin{array}{c}\text { Avg grain wt } \\
\text { 8\% moisture }\end{array}$ & Avg dry matter & $\mathrm{g} / 1000$ seeds \\
\hline & & grams & \\
Low salinity & $\mathbf{7 1 3 \mathrm { a }}$ & $607 \mathrm{a}$ & 46.9 \\
Medium salinity & $691 \mathrm{a}$ & $560 \mathrm{a}$ & 46.9 \\
High salinity & $543 \mathrm{~b}$ & $413 \mathrm{~b}$ & 46.0 \\
Altamont clay loam & $806 \mathrm{a}$ & $664 \mathrm{a}$ & 45.6 \\
Holtville clay loam & $633 \mathrm{~b}$ & $535 \mathrm{~b}$ & 45.6 \\
San Emigdio sandy loam & $615 \mathrm{~b}$ & $511 \mathrm{~b}$ & 47.6 \\
Greenfield sandy loam & $586 \mathrm{~b}$ & $\mathbf{4 3 7 \mathrm { c }}$ & $\mathbf{4 7 . 5}$ \\
\hline
\end{tabular}

* Means followed by a common letter were not statistically separable at the $5 \%$ level.

data from solution samples taken at the beginning of the first crop (Feb. 1, 1976) and on day 449 (April 25, 1977) in six of the lysimeters. Sulfate deficits are assumed to be due to gypsum precipitation. Magnesium and sodium deficits are assumed to have replaced calcium on the exchange complex. The difference between the sulfate deficit and the deficit in the sum of cations represents the loss of calcium not due to gypsum precipitation, which is assumed to be due to $\mathrm{CaCO}_{3}$ precipitation. Chloride deficits, which should be zero if the sampling is accurate, are small in all six cases.

Calcium carbonate precipitation was indicated in all cases except lysimeter 11, which also had the smallest percent precipitation. We felt that one of the sodium solution samples taken in April, 1977, was abnormally high, which would result in an underprediction of the amount of calcium released from exchange, and a corresponding underprediction of $\mathrm{CaCO}_{3}$ precipitation. The other five lysimeters averaged close to 50 percent precipitation, which is consistent with the values calculated from salinity sensor readings (Tables 4,7 , 10).

Values of Sodium Adsorption Ratio (SAR) by depth for the six lysimeters are given in Table 13. Because of the large amount of precipitation of calcium salts, these values are high in the top $50 \mathrm{~cm}$, although no apparent reductions in soil hydraulic conductivity were observed. Average SAR was lower for the Holtville clay loam lysimeters than for the Greenfield sandy loam lysimeters receiving the same irrigation treatment, undoubtedly as a result of the higher Cation Exchange Capacity (CEC) in the former.

\section{Yield-salinity correlations}

Yields of the sorghum and second wheat crop tests were significantly reduced by soil salinity. Table 14 presents correlation coefficients for the yields of individual lysimeters against various indices of salinity. The first wheat crop, not affected by soil salinity, had no meaningful correlations. The sorghum and second wheat crops had moderate negative correlations for yield $v s$. a variety of irrigation-, drainage-, and soil-salinity-weighted indices, with no correlation stronger than -0.79 . The weakest correlation for both experiments was yield weighted against $C_{i r r}$ ln $(1 / L F) /(l-L F)$, which is the theoretical average salinity of the water taken up by plant roots, neglecting dispersion, when steady state has been reached (Raats, 1974). Contrary to the results of Ingvalson, Rhoades, and Page (1976), we did not find that time-averaged indices correlated better than indices evaluated from salinity measurements taken at the end of the crop. In fact, the index which correlated best with yield for both experiments combined was EC of the drainage water at 


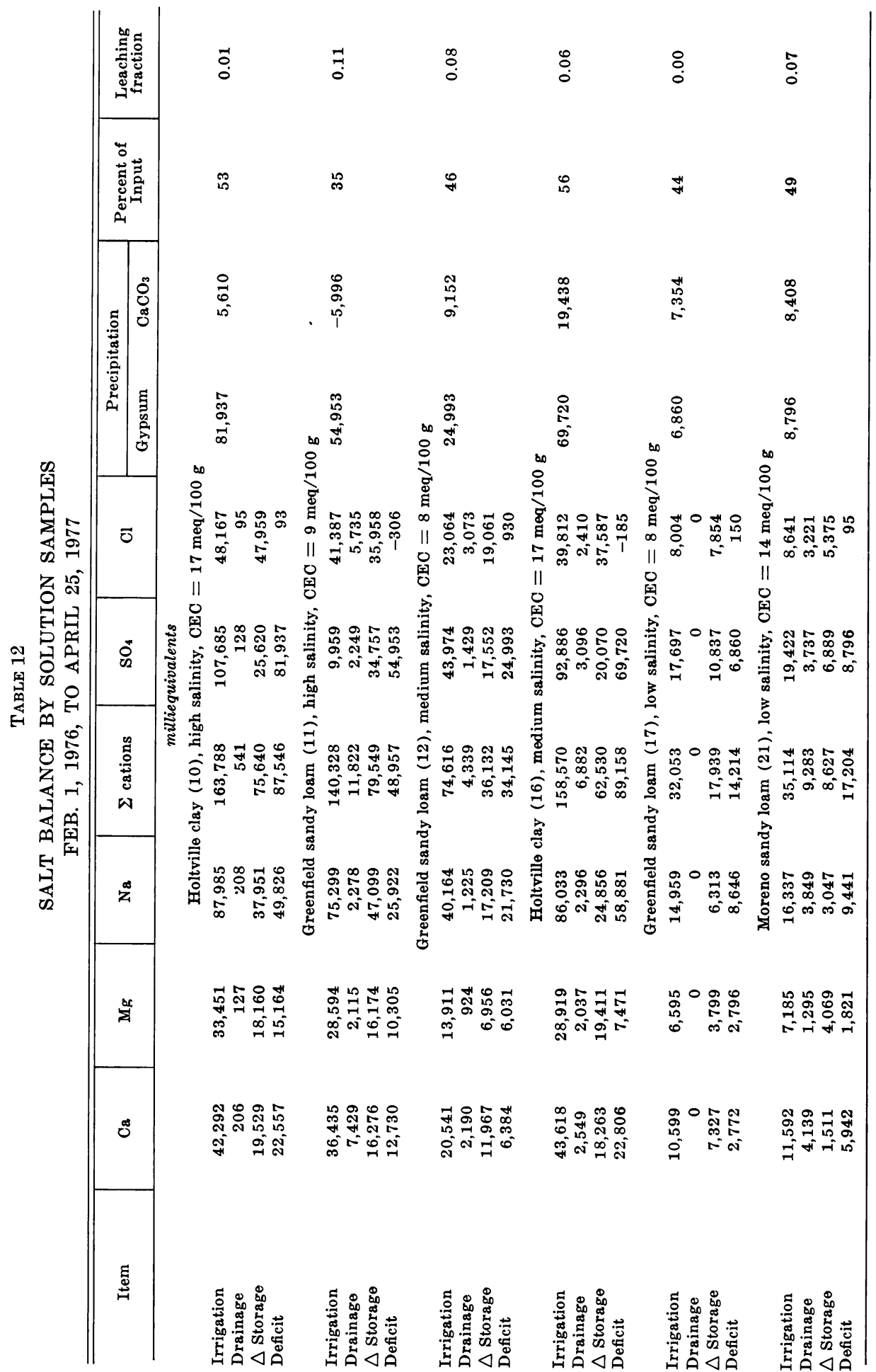


TABLE 13

SODIUM ADSORPTION RATIO (SAR) VS. DEPTH IN SIX LYSIMETERS

\begin{tabular}{l|c|r|r|r|r|r|r}
\hline \multirow{2}{*}{ Soil and lysimeter number } & \multirow{2}{*}{$\begin{array}{c}\text { Irrigation } \\
\text { salinity level }\end{array}$} & \multicolumn{5}{|c}{ Depth of measurement for SAR } \\
\cline { 3 - 7 } & & $5 \mathrm{~cm}$ & $20 \mathrm{~cm}$ & $50 \mathrm{~cm}$ & $80 \mathrm{~cm}$ & $120 \mathrm{~cm}$ & $145 \mathrm{~cm}$ \\
\hline Holtville clay loam 10 & high & 20.5 & 20.4 & 19.1 & 13.5 & 6.3 & 3.0 \\
Greenfield sandy loam 11 & high & 31.3 & 20.8 & 33.6 & 23.6 & 8.3 & 2.6 \\
Greenfield sandy loam 12 & medium & 25.0 & 9.8 & 15.1 & 13.1 & 4.8 & 5.2 \\
Holtville clay loam 16 & medium & 16.8 & 15.1 & 7.8 & 4.0 & 7.2 & 3.7 \\
Greenfield sandy loam 17 & low & 6.8 & 8.1 & 10.4 & 2.3 & 2.3 & 3.0 \\
San Emigdio sandy loam 21 & low & 9.5 & 3.2 & 3.8 & 3.1 & 7.0 & 5.9 \\
\hline
\end{tabular}

TABLE 14

CORRELATION BETWEEN GRAIN YIELD AND SALINITY INDICES

\begin{tabular}{|c|c|c|c|}
\hline Item & $\begin{array}{l}\text { First wheat } \\
\text { crop }\end{array}$ & $\begin{array}{l}\text { Sorghum } \\
\text { crop }\end{array}$ & $\begin{array}{l}\text { Second wheat } \\
\text { crop }\end{array}$ \\
\hline $\begin{array}{l}Y \text { vs. } E_{i r r} C^{*} \\
Y \text { vs. }\left(E_{i r r} V_{1 r r}-E_{d r} V_{d r}\right) /\left(V_{i r r}-V_{d r}\right) \dagger \\
Y \text { vs. }\left[\left(C l^{-}+1 / 2 \mathrm{SO}_{4}=\right)_{i r r}+\left(C l^{-}+1 / 2 \mathrm{SO}_{4}=\right) d r\right] / 2\end{array}$ & $\begin{array}{l}0.39 \\
0.40 \\
-\end{array}$ & $\begin{array}{l}-0.65 \\
-0.64 \\
-\end{array}$ & $\begin{array}{l}-0.64 \\
-0.59 \\
-0.79\end{array}$ \\
\hline $\begin{array}{l}Y \text { vs. } E C_{d r} \text { at harvest } \\
Y \text { vs. } E C_{\max } \text { at harvest } \\
Y \text { vs. } E C_{\min } \text { at harvest } \\
Y \text { vs. } E C_{20} \mathrm{~cm} \text { at harvest } \\
Y \text { vs. }\left(E C_{i r r}+E C_{d r}\right) / 2 \text { at harvest }\end{array}$ & $\begin{array}{l}0.46 \\
0.49 \\
0.23 \\
0.45 \\
0.43\end{array}$ & $\begin{array}{l}-0.79 \\
-0.49 \\
-0.59 \\
-0.56 \\
-0.68\end{array}$ & $\begin{array}{l}-0.71 \\
-0.69 \\
-0.77 \\
-0.66 \\
-0.75\end{array}$ \\
\hline $\begin{array}{l}Y \text { vs. time-averaged } E C_{d r} \\
Y \text { vs. time-averaged } E_{5} \mathrm{~cm} \\
Y \text { vs. time-averaged } E_{120} \mathrm{~cm}\end{array}$ & $\begin{array}{l}0.23 \\
0.22 \\
0.41\end{array}$ & $\begin{array}{l}-0.55 \\
-0.55 \\
-0.64\end{array}$ & $\begin{array}{l}-0.57 \\
-0.54 \\
-0.64\end{array}$ \\
\hline $\mathbf{Y}$ vs. $\mathrm{EC}_{\mathrm{irr}} \ln (\mathrm{l} / \mathrm{LF}) /(\mathrm{l}-\mathrm{LF})$ & 0.70 & -0.25 & -0.44 \\
\hline
\end{tabular}

* $\mathrm{EC}=$ electrical conductivity.

$\dagger V_{i r r}=$ volume of irrigation water during crop; $V_{d r}=$ volume of drainage water during crop.

harvest, which is consistent with the findings of Rhoades and Merrill (1976).

\section{Water uptake distribution}

Calculating a water-uptake distribution from in situ measurements of water potential and water content contains great error if soil variability is high (Fluhler et al., 1977), and we were unable to use our tensiometer and neutronprobe readings for this purpose. However, solution concentration measurements may be used to imply water uptake provided certain assumptions are met.

If steady-state salt concentrations have developed to a depth $Z$, then chloride concentrations should (neglecting diffusion and dispersion) approximately obey the equation

$$
C l(Z) \cdot J w(Z)=C l_{i r r} \cdot I_{i r r}
$$

where $J w$ is water flux and $I$ is irriga- tion flux. This can be used to solve for $J w$ and for the water uptake $I-J w$ between the surface and $Z$. Fractional water uptake is obtained as $(I-J w) / E T$.

Salinity sensor measurements of EC may not be used in an equation similar to Eq. 8 because of salt precipitation. To correct for precipitation, we have used the chemical equilibrium model to calculate EC as a function of leaching fraction for each of the three irrigation waters in Table 1. As these calculated concentrations were to be used near the soil surface, we assumed the $\mathrm{CO}_{2}$ concentration to be 1.0 percent. Figure 12 shows the results of this calculation plotted against fractional uptake $(I-J w) / E T$, assuming an overall leaching fraction of zero. Using this figure, it is possible to estimate the fractional uptake occurring above a salinity sensor measuring a steady state value of EC. 
TABLE 15

FRACTIONAL WATER UPTAKE DETERMINED FROM SALT CONCENTRATIONS

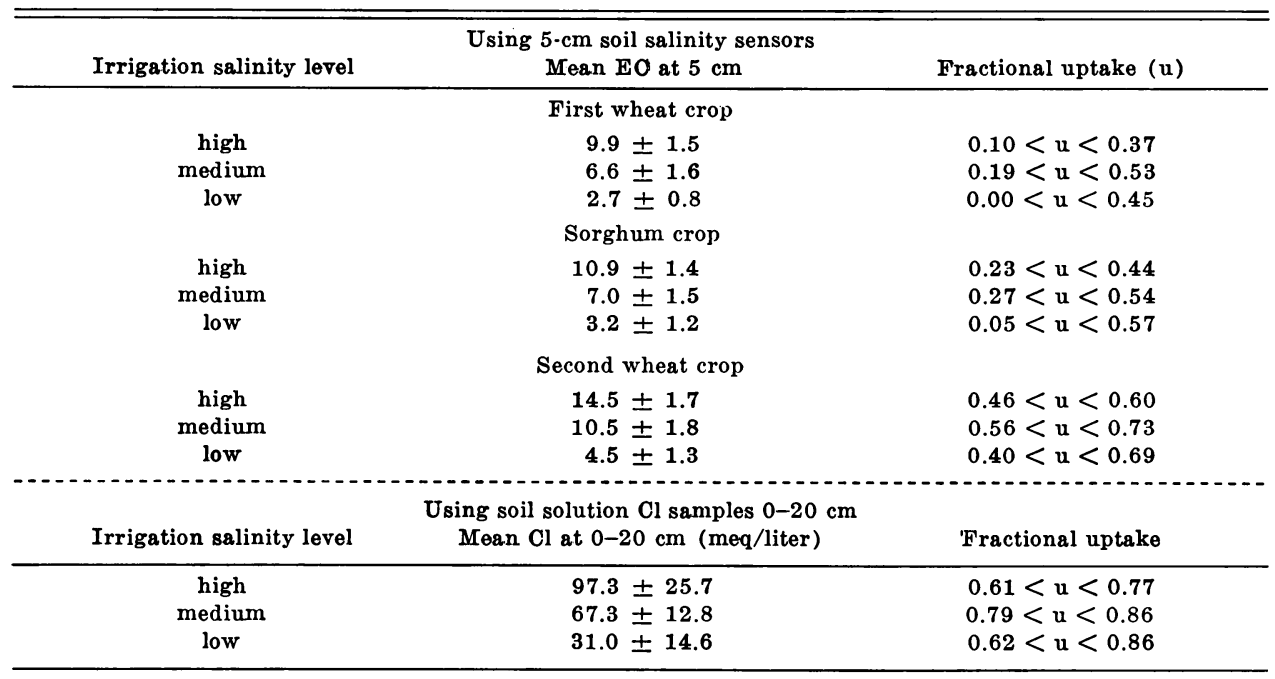

There are several sources of error in this estimate of uptake. First, salt precipitation in our experiments exceeded the steady state rates, so that Fig. 12 will underestimate the fractional up-

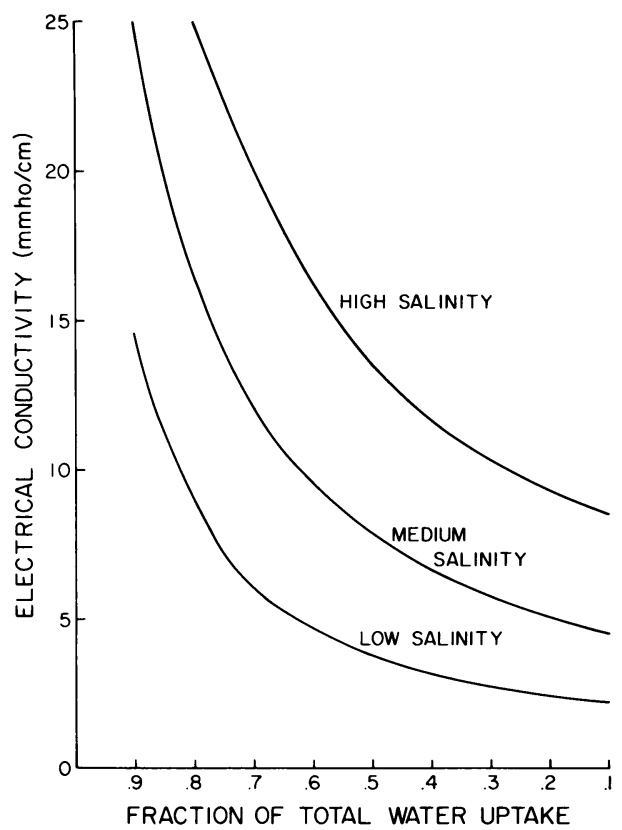

Fig. 12. Soil water electrical conductivity vs. fractional water uptake calculated from equilibrium model. take occurring above a sensor. Second, our leaching fractions were not all zero as assumed in Fig. 12. However, fractional water uptake above $Z$ for a root zone with leaching fraction ( $l f$ ) and concentration $E C(Z)$, may be obtained from Fig. 12 by multiplying the corresponding uptake by $1 /(1-l f)$. Finally, in our experiments soil salt concentrations were not constant even when steady state had been reached, so that time averages had to be taken.

Table 15 shows average water uptake in the 0 to $5 \mathrm{~cm}$ depth, obtained from salinity sensor readings and from chloride samples taken during the second wheat crop. The $\mathrm{EC}$ readings at $5 \mathrm{~cm}$ were time averaged over the crop growth period after saline irrigation water had penetrated to $20 \mathrm{~cm}$ for each crop.

From the results in Table 15, it is clear that a large fraction of the water uptake occurs near the soil surface, and that this fraction increases as the soil becomes progressively salinized in subsequent experiments. Because the plants were irrigated daily, the soil near the surface remained moist even though much of the water extraction occurred 
TABLE 16

ROOT DENSITY AT END OF FIRST WHEAT EXPERIMENT FOR HIGH-SALINITY ALTAMONT CL, NO. 8

\begin{tabular}{ccc}
\hline \hline Depth & $\begin{array}{c}\text { Root density } \\
\left(\mathrm{g} / \mathrm{cm}^{3} \text { soil }\right) \times 10^{8}\end{array}$ & $\begin{array}{c}\text { Root mass distribution } \\
(\% \text { of total root mass })\end{array}$ \\
\hline$c m$ & & \\
$0-20$ & 176.5 & 64.5 \\
$20-40$ & 23.2 & 8.5 \\
$40-60$ & 22.3 & 8.1 \\
$60-80$ & 19.6 & 7.1 \\
$80-100$ & 17.9 & 6.5 \\
$100-120$ & 9.2 & 3.4 \\
$120-150$ & 3.4 & 1.8 \\
\hline
\end{tabular}

there. Further evidence of shallow water uptake is found in the root density-depth distribution (Table 16) for high-salinity Altamont clay loam lysimeter No. 8, taken at the end of the first wheat crop. The shallow rooting, with 65 percent of all roots in the top $20 \mathrm{~cm}$, is consistent with the high apparent water uptake near the surface, as determined from the salinity sensors.

\section{THEORETICAL CALCULATIONS}

\section{Water flow model}

Uncertainty about the gravity flow hypothesis (unit hydraulic gradient) makes predictions with the water model subject to potential error. To test this assumption of gravity flow, we compared the model with a finite difference solution of the exact differential equation over a 40-day period. We found agreement within 7 percent with calculated water flux as a function of depth, and reasonable correspondence with watercontent predictions. A further test of the unit gradient assumption is possible by calculation of steady downward flow, with water uptake expressed as an exponentially decreasing function of depth. The equation and surface boundary conditions are

$$
\begin{gathered}
\frac{-d}{d Z}\left[K(h)\left(\frac{d h}{d z}+1\right)\right]+S(Z)=0 \\
-K(h)\left(\frac{d h}{d Z}+1\right)=-I
\end{gathered}
$$

where $h$ is the soil water head, and $S(z)$ is the water uptake function which satisfies

$$
\int_{-L}^{O} S(Z) d Z=E T
$$

with $L$ the depth of the root zone. For the water uptake function $S(z)$, we assume the form

$$
S(Z)=A \exp (+B Z)
$$

It has been shown (Feddes et al., 1974) that numerous root-density data can be adequately described by equation 12 . For the simulation, $B$ was defined so that the uptake at $120 \mathrm{~cm}$ was 0.1 of the surface value. Figure 13 is a plot of the ratio of the gravitational component of downward flow $K(h)$ to the total downward flow $K(h)(d h / d Z+1)$ as a function of depth for various leaching fractions $L F=(I-E T) / I$ using an exponential approximation, $K(h)=7.8 \mathrm{exp}$ $(.09 \mathrm{~h})$ to the measured data of the Altamont soil. It is evident that only at extremely small leaching fractions do sufficient water-potential gradients develop to make the gravity-flow assumption unreasonable. The effect of the 


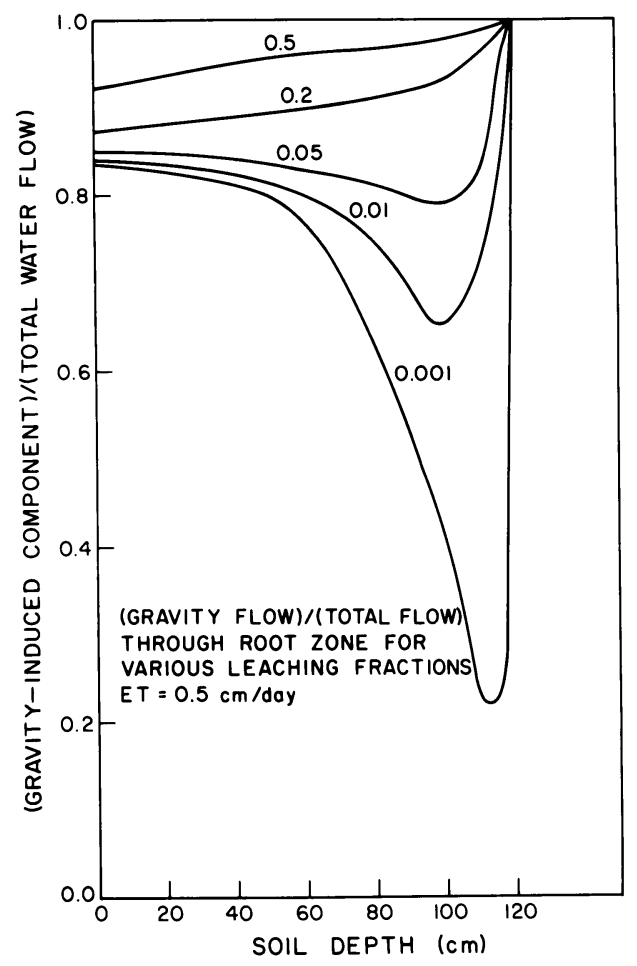

Fig. 13. Ratio of gravity component to total flow for steady downward flow at a constant leaching fraction.

gravity-flow model is to associate a slightly different water content profile with a downward-flux profile, than one would obtain from a complete numerical solution of the unsaturated flow equation.

\section{Travel times}

A natural question to ask about a system with an extended root distribution and a positive leaching fraction is: How long will it take material introduced at the surface to travel through the root zone to a given depth in the soil? A simplified answer is obtained if we assume that the time to travel a distance $L$ through the soil is given by (Raats, 1975):

$$
t=\int_{0}^{L} \frac{d Z}{\left(J_{w} / \theta\right)}
$$

where $J_{w} / \theta$ represents a mean pore water velocity. Figure 14 plots the time to travel $120 \mathrm{~cm}$ as a function of leaching fraction for several assumed root distributions. Two points are to be stressed here: First, travel time depends largely on the extraction distribution of the root zone, even for a uniform total extraction $(0.5 \mathrm{~cm} /$ day in Fig. 14). Second, travel times for small leaching fractions are very long, suggesting that equilibrium times may exceed one year, a fact that has been qualitatively substantiated by our experimental results (Fig. 11). These traveltime calculations must be considered only as rough estimates, because they do not take into account variations in ET, the effect of solute dispersion, or the influence of cation exchange.

\section{Spatial variability}

Some means to achieve low-leaching fractions is essential to a high-frequency irrigation and salinity management system. In the presence of a variable external potential evapotranspira-

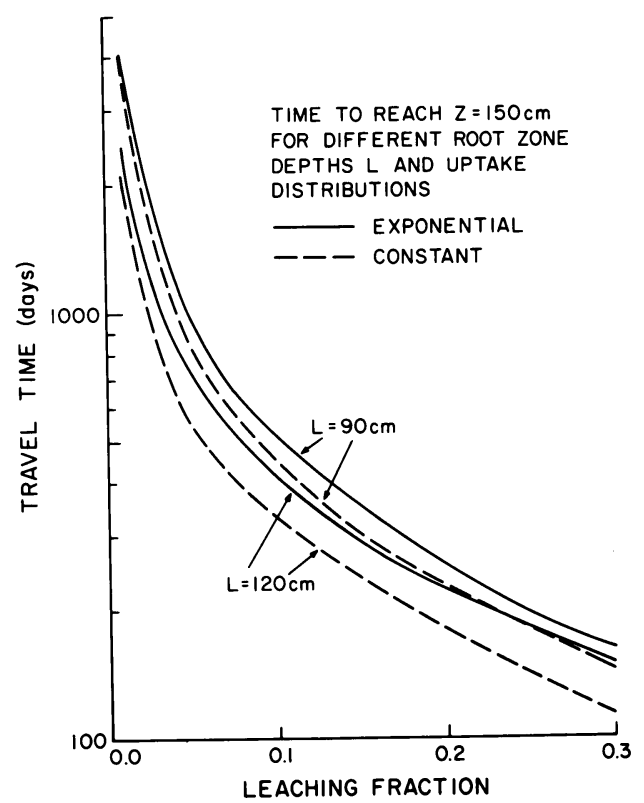

Fig. 14. Travel time through root zone as functions of leaching fraction and uptake distribution. 
tion, this implies that the surface input would have to be adjusted to keep the leaching fraction relatively constant. The long travel time shown in Fig. 14 indicates that feedback originating from subsurface measurements may be subject to a large phase lag in addition to any variations caused by heterogeneous soil characteristics. Another disadvantage to the use of tensiometers for irrigation scheduling, when evapotranspiration is variable, is that a constant water potential at a location in the root zone will not result in a constant leaching fraction. Thus, the threshold water potential used to initiate irrigation must be adjusted during the season.

Determining the amount of irrigation water needed by using salinity sensor readings at a shallow depth to achieve a steady EC value that is associated with a given leaching fraction is one way of minimizing the phase lag. However, spatial variations in soil salinity (Fig. 5), reduction of EC by precipitation (Table 5), and diffusion and dispersion effects on solute distribution can greatly influence salinity concentrations within a root zone.

Figure 15 is a plot of steady-state salt concentrations determined from the flow equation

$$
J_{s}=C_{I} I=-\theta D \frac{d C}{d Z}+J_{w} C
$$

where $C_{I}$ is input concentration and $D$ is the effective diffusion-dispersion coefficient. The data in Figure 15 were calculated assuming ET of $0.5 \mathrm{~cm} /$ day, a $l f$ of 0.05 , and values of $D$ up to $5 \mathrm{~cm}$ per day-well within the range of experimental measurements (Nielsen and Biggar, 1962; Biggar and Nielsen, 1976). The large influence of diffusion and dispersion apparent in this figure results from the sharp concentration gradients found with low-leaching fractions. It is clear that knowledge of this coefficient will be needed to make accurate predictions of steady-state salin-

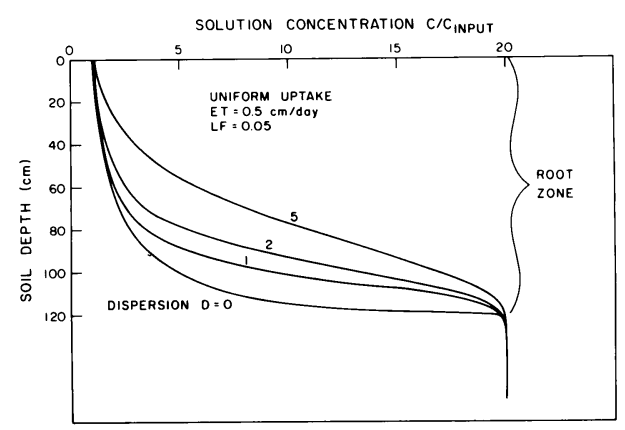

Fig. 15. Steady salt concentration profiles as functions of dispersion coefficient size.

ity distributions. However, the magnitude of $D$ within these limits does not critically influence short-term calculations.

\section{Transition profiles}

Even without considering spatial variability or measurement error, it would be extremely difficult to interpret salinity measurements within the root zone during the transition period. This is illustrated in Fig. 16, which shows solute distributions with depth for three leaching fractions, and at three times after the introduction of saline water to an initially salt-free soil. The assumptions were a root zone depth of $30 \mathrm{~cm}$; water uptake, totalling $0.5 \mathrm{~cm}$ per day, exponentially decreasing through the root zone; and $D$ equalling $1.5 \mathrm{~cm}^{2}$ per day. The data showed that one would have difficulty inferring a leaching

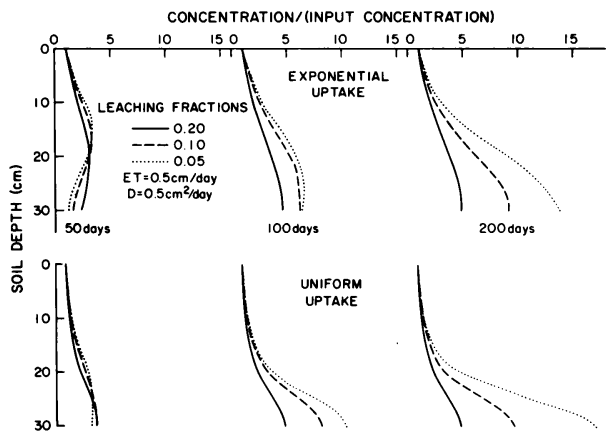

Fig. 16. Calculated transient salt concentrations as functions of leaching fraction and uptake distribution. 


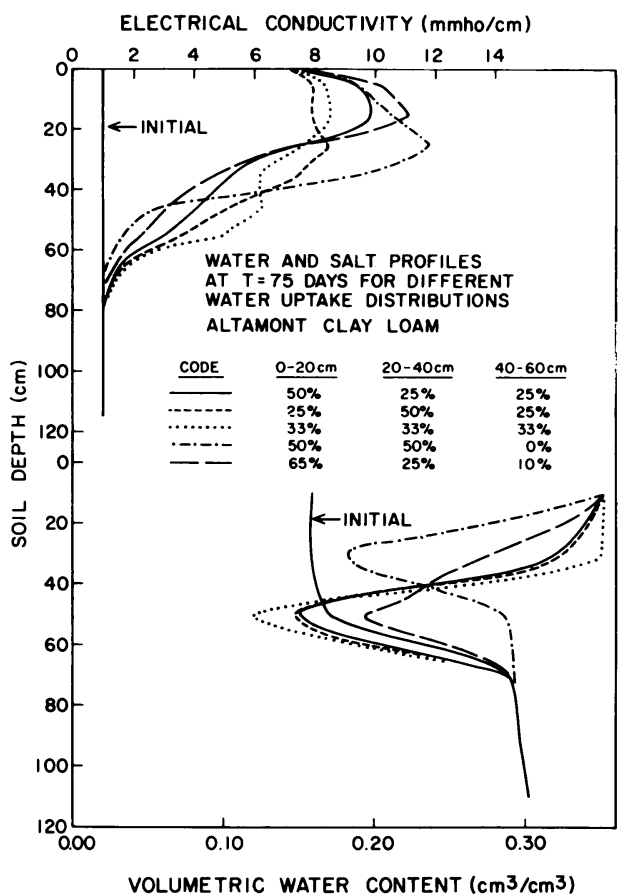

Fig. 17. Calculated water and salt profiles after 75 days of high-salinity irrigation as functions of root zone uptake distribution shape.

fraction from a solute concentration value at any time before the attainment of steady state. Furthermore, Jury, Fluhler, and Stolzy (1977) have shown that lateral variations in the water uptake distribution have a large influence on solute concentration distributions within the root zone, even for the same total extraction (Fig. 17).

\section{Chemical equilibrium model}

Analysis of the ionic composition of soil and drainage water samples (Table 12), and salinity sensor readings (Tables 4, 7, 10), led us to conclude that substantial precipitation of applied salt occurred within the root zone. The chemical equilibrium model can be used to predict steady-state rates of precipitation as a function of $\mathrm{CO}_{2}$ distribution, water uptake distribution, leaching fraction, and irrigation water composition.
Table 17 shows the predicted amounts of precipitation occurring within the root zone, assuming a water uptake distribution of $40,30,20$, and 10 percent for the first- through fourth-quarter depths of the root zone, and corresponding $\mathrm{CO}_{2}$ percentages in the soil air of 1.0, 1.5, 2.3, and 3.0 percent.

Several conclusions may be drawn from the simulation: 1) Both gypsum and $\mathrm{CaCO}_{3}$ are predicted to precipitate within the root zone for all LF (up to $0.40)$; 2) Gypsum precipitation greatly exceeds $\mathrm{CaCO}_{3}$ precipitation at all $\mathrm{LF}$; 3) The fraction of applied salt precipitated decreases gradually as LF increased from a maximum of 0.27 at $\mathrm{LF}=0.05$ to 0.23 at $\mathrm{LF}=0.20$, the highest leaching fraction in our experiment.

The first two conclusions are consistent with the ion balance made in our experiment (Table 12). Our fractional

TABLE 17

CALCULATED STEADY-STATE $\mathrm{CaCO}_{3}$ AND CaSO, PRECIPITATED IN DEPTH SEGMENTS PER YEAR FOR DIFFERENT LF USING HIGH.

SALINITY IRRIGATION WATER*

\begin{tabular}{|c|c|c|}
\hline \multirow{2}{*}{$\begin{array}{l}\text { Depth segment } \\
\text { (from root zone) }\end{array}$} & \multicolumn{2}{|c|}{ Precipitation } \\
\hline & $\mathrm{CaCO}_{3}$ & $\mathrm{CaSO}_{4}$ \\
\hline & \multicolumn{2}{|c|}{$\begin{array}{c}\text { metric tons } / \text { ha } \\
\mathrm{LF}=0.05,26.8 \% \text { of applied sal }\end{array}$} \\
\hline 0 -surface & $\mathbf{3 . 1 3}$ & 0.00 \\
\hline 1st quarter & -0.64 & 9.54 \\
\hline 2nd quarter & -0.15 & 10.39 \\
\hline 3rd quarter & 0.56 & 5.66 \\
\hline 4th quarter & 0.49 & 2.16 \\
\hline \multirow[t]{2}{*}{ Total } & 3.39 & 27.75 \\
\hline & \multicolumn{2}{|c|}{$L F=0.20,22.8 \%$ of applied salt } \\
\hline 0-surface & 3.71 & 0.00 \\
\hline 1st quarter & -0.93 & 8.92 \\
\hline 2nd quarter & -0.54 & 10.79 \\
\hline 3rd quarter & 0.27 & 6.30 \\
\hline 4th quarter & 0.20 & 2.95 \\
\hline \multirow[t]{2}{*}{ Total } & 2.71 & 28.95 \\
\hline & \multicolumn{2}{|c|}{$\mathrm{LF}=0.4,16.9 \%$ of applied salt } \\
\hline 0-surface & 4.95 & 0.00 \\
\hline 1st quarter & -1.53 & 7.57 \\
\hline 2nd quarter & -1.28 & 11.68 \\
\hline 3rd quarter & -0.20 & 7.04 \\
\hline 4th quarter & -0.16 & 3.57 \\
\hline Total & 1.78 & 29.87 \\
\hline
\end{tabular}

* LF =leaching fraction $; \mathrm{EC}=$ electrical conductivity (7.1); ET = evapotranspirstion $(180 \mathrm{~cm} / \mathrm{yr})$. 
precipitation, however, averaged over 0.50 for the three crop seasons. During the transitional period when soil salinity is increasing, exchange adsorption will bring $\mathrm{Ca}^{++}$ions into solution, increasing the amount of gypsum and $\mathrm{CaCO}_{3}$ precipitation. Until steady state has been obtained, precipitation rates should exceed the predicted rates, which assume no cation exchange-and solution concentrations should be correspondingly lower.

Further research is needed on the characteristics and duration of the transitional period before steady state, in order to estimate plant yield and environmental implact of a given irrigation management policy.

\section{CONCLUSIONS}

From the experimental and theoretical information gathered in this study we conclude:

1) Salt-tolerant crops irrigated with saline water up to $7.1 \mathrm{mmho} / \mathrm{cm} \mathrm{EC}$ can produce reasonably high yields, even when the soil profile is initially salinized.

2) Calculation of water uptake distribution from salt concentrations indicates that 50 percent or more of the water extraction was occurring within $5 \mathrm{~cm}$ of the surface over most of the experiment. This is a consequence both of the high salinity of the irrigation water and of daily irrigation.

3) Substantial amounts of precipitation, averaging over 50 percent of applied salt, occurred in the soil profile within the lysimeters. Ionic composition analysis indicated that predominantly gypsum $\left(\mathrm{CaSO}_{4}\right)$ salts were precipitating. The large precipitation is a consequence of the unusual irrigation water composition characteristic of cooling tower blowdown water.
4) Characteristic travel times for full-profile salinization are very long for the small leaching fractions used in these experiments. The salt distribution has reached steady state only above 50 $\mathrm{cm}$ after 500 days of high-frequency irrigation.

5) Spatial variability of soil-water transport properties, evapotranspiration losses, and depth-equivalent salinity sensor reading was very high in this experiment. It would be difficult to calculate leaching fractions from soilbased measurements during the transient phase of profile salinization.

6) Chemical precipitation amounts greatly exceed steady-state values predicted from an equilibrium model. It is probable that removal of calcium ions from the soil exchange complex created a larger amount of gypsum $\left(\mathrm{CaSO}_{4}\right)$ precipitation than will occur when solution-exchange equilibrium has been achieved everywhere in the profile after salinization is complete.

\section{ACKNOWLEDGMENT}

The authors would like to thank the for financial assistance on this project. Southern California Edison Company

\section{LITERATURE CITED}

BERNSTEIN, L.

1974. Crop growth and salinity. Agronomy 17: 39-54.

BigaAR, J. W., and D. R. NiELsen

1976. Spatial variability of the leaching characteristics of a field soil. Water Resources Res. 12: 78-84. 
Doorenbos, J., and W. O. PruitT

1975. Crop water requirements. Irrigation and Drainage Paper 24. FAO, Rome.

DUTT, G. R., and K. K. TANJI

1962. Predicting concentrations of solutes in water percolated through a column of soil. J. Geophys. Res. 67: 3437-39.

Feddes, R. A., E. Bresler, and S. P. Neuman

1974. Field test of a modified numerical model for water uptake by root systems. Water Resources Res. 10: 1199-1206.

Fluhler, H., M. S. Ardakani, T. E. Szuszkiewicz, and L. H. Stolzy

1977. Field measured water uptake of sudan grass roots affected by fertilization. Agron. J. 69: 269-73.

Ingvalson, R. D., J. D. Rhoades, and A. L. Page

1976. Correlation of alfalfa yield with various indexes of salinity. Soil Sci. 122: 145-53.

Jensen, M. E.

1975. Scientific irrigation scheduling for salinity control of irrigation return flows. Environmental Protection Technology Series 600/2-75-064.

Jury, W. A., H. Fluhler, and L. H. STOLzY

1977. Influence of soil properties, leaching fraction and plant water uptake on solute concentration distribution. Water Resources Res. 13: 645-50.

KING, L. G., and R. J. HANKS

1975. Management practices affecting quality and quantity of irrigation return flows. Environmental Protection Technology Series 660/2-75-005.

McNeal, B. L.

1968. Predicting of the effect of mixed salt solutions on soil hydraulic conductivity. Soil Sci. Soc. Amer. Proc. 32: 190-93.

MCNeAL, B. L., J. D. Oster, and J. T. HATCher

1970. Calculation of electrical conductivity from solution composition data as an aid to in-situ estimation of soil salinity. Soil Sci. 110: 405-14.

Moses, R. J.

1972. Where is the water coming from? In Cooling Towers. Amer. Inst. Chem. Eng. CEP Tech. Man. pp. 42-46.

Nielsen, D. R., and J. W. Biggar

1962. Miscible displacement: III. Theoretical considerations. Soil Sci. Soc. Amer. Proc. 26: 216-21.

Oster, J. D., and B. L. McNeAL

1971. Computation of soil solution composition variation with water content for desaturated soils. Soil Sci. Soc. Amer. Proc. 35: 436-42.

OSTER, J. D., and J. D. RHOADES

1975. Calculated drainage water compositions and salt burdens resulting from irrigation with river waters in the Western United States. J. Environ. Qual. 4: 73-79.

Pratt, P. F., G. H. Cannell, M. J. Garber, and F. L. Bair

1967. Effect of three nitrogen fertilizers on gains, losses and distribution of various elements in irrigated lysimeters. Hilgardia 38(8): 265-83.

Pratt, P. F., S. Davis, and A. E. LaAg

1977. Manure management in an irrigated basin relative to salt leaching to groundwater. J. Env. Qual. 6: 397-401.

RaAts, P. A. C.

1974. Movement of water and salts under high frequency irrigation. Proc. 2nd Int. Drip Irrig. Congr.: 222-27. San Diego, CA.

1975. Distribution of salts in the root zone. J. Hydrol. 27: 237-48.

RAWLINS, S. L.

1974. Principles of managing high frequency irrigation. Soil Sci. Soc. Amer. Proc. 37: 626-29.

1976. Tailoring salt management solutions to basin hydrology. Proc. of Conf. "Salt and Salinity Management," Santa Barbara, CA.

RHOAdes, J. D.

1974. Drainage for salinity control. Agronomy 17: 433-70.

Rhoades, J. D., R. D. Ingvalson, J. M. Tucker, and M. Clark

1973. Salts in irrigation waters. Soil Sci. Soc. Amer. Proc. 37: 770-74.

Rhoades, J. D., J. D. Oster, R. D. Ingvalson, J. M. Tucker, and M. Clark

1974. Minimizing the salt burdens of irrigation drainage waters. J. Env. Qual. 3:311-16.

RHOADES, J. D., and S. MERRILL

1976. FAO Soils Bull. 31. pp. 69-109. 
RHoAdes, J. D., and D. L. Suarez

1976. Minimized leaching for reducing water quality degradation: Advantages and limitations. Proc. of Conf. "Salt and Salinity Management," Santa Barbara, CA.

Rhoades, J. D., and J. vaN SchilfaAarde

1976. An electrical conductivity probe for determining soil salinity. Soil Sci. Soc. Amer. J. 40:647-50.

ROSE, C. W., W. R. STERN, and J. E. DRUMMOND

1965. Determination of hydraulic conductivity as a function of depth and water content for soil in situ. Aust. J. Soil Res. 3:1-9.

van Schilfaadrde, J., L. Bernstens, J. D. Rhoades, and S. L. Rawlins

1974. Irrigation management for salt control. J. Irrig. Drainage Div., American Society of Civil Engineers 100:321-38.

Tanji, K. K., G. R. DUTT, J. L. Paul, and L. D. Doneen

1967. Quality of percolating waters. Hilgardia 38(9) : 285-347. 